\title{
The Acquisition of Target Dependence by Developing Rat Retinal Ganglion Cells
}

\author{
Colette Moses, ${ }^{1, *}$ Lachlan P.G. Wheeler, ${ }^{1, *}$ Chrisna J. LeVaillant, ${ }^{1}$ Anne Kramer, ${ }^{1}$ Marisa Ryan, ${ }^{1}$ \\ Greg S. Cozens, ${ }^{1}{ }^{\oplus}$ Anil Sharma, ${ }^{1,3}$ Margaret A. Pollett, ${ }^{1}$ Jennifer Rodger, ${ }^{2,4}$ and Alan R. Harvey ${ }^{1,4}$
}

DOI:http://dx.doi.org/10.1523/ENEURO.0044-14.2015

${ }^{1}$ School of Anatomy, Physiology, and Human Biology, The University of Western Australia, Perth, Western Australia 6009, Australia, ${ }^{2}$ School of Animal Biology, The University of Western Australia, Perth, Western Australia 6009, Australia, ${ }^{3}$ Department of Neuroscience, Karolinska Institutet, 17177 Stockholm, Sweden, ${ }^{4}$ Western Australian Neuroscience Research Institute, Nedlands, Western Australia 6009, Australia

\begin{abstract}
Similar to neurons in the peripheral nervous system, immature CNS-derived RGCs become dependent on target-derived neurotrophic support as their axons reach termination sites in the brain. To study the factors that influence this developmental transition we took advantage of the fact that rat RGCs are born, and target innervation occurs, over a protracted period of time. Early-born RGCs have axons in the SC by birth (P0), whereas axons from late-born RGCs do not innervate the SC until P4-P5. Birth dating RGCs using EdU allowed us to identify RGCs (1) with axons still growing toward targets, (2) transitioning to target dependence, and (3) entirely dependent on target-derived support. Using laser-capture microdissection we isolated $\sim 34,000$ $\mathrm{EdU}^{+} \mathrm{RGCs}$ and analyzed transcript expression by custom qPCR array. Statistical analyses revealed a difference in gene expression profiles in actively growing RGCs compared with target-dependent RGCs, as well as in transitional versus target-dependent RGCs. Prior to innervation RGCs expressed high levels of BDNF and CNTFR $\alpha$ but lower levels of neurexin 1 mRNA. Analysis also revealed greater expression of transcripts for signaling molecules such as MAPK, Akt, CREB, and STAT. In a supporting in vitro study, purified birth-dated P1 RGCs were cultured for 24-48 $\mathrm{h}$ with or without BDNF; lack of BDNF resulted in significant loss of early-born but not late-born RGCs. In summary, we identified several important changes in RGC signaling that may form the basis for the switch from target independence to dependence.
\end{abstract}

Key words: BDNF; neurotrophic factors; programmed cell death; retinal ganglion cells; target dependence

\section{Significance Statement}

During brain development many neurons die around the time neural connections are established. This cell loss is thought to be from competition between neurons for limited amounts of target-derived trophic support; responsive neurons receiving sufficient amounts of such factors survive. But what factors sustain developing neurons prior to target innervation? We took advantage of the fact that rat RGCs are born, and target innervation occurs, over a protracted time period. Using laser-capture microdissection of birth-dated RGCs we compared gene expression in neurons prior to, during, and after innervation of central targets. We identified numerous changes in RGC signaling that may form the basis for the switch from target independence to dependence and from axonal elongation to arborization/synaptogenesis. 


\section{Introduction}

Programmed cell death (PCD) occurs throughout the developing nervous system and is a crucial step in the maturation of neural circuitry. For example, in the developing rat visual system PCD results in a loss of at least $50 \%$ of the maturing RGC population (Dreher et al., 1983; Perry et al., 1983; Crespo et al., 1985; Harvey and Robertson, 1992). A key element in regulating the onset and distribution of PCD is the availability of neurotrophic factor support. In both the CNS and PNS, removal or addition of neurotrophic factors, respectively, increases or decreases the amount of PCD (PNS: Levi-Montalcini and Angeletti, 1968; Thoenen and Barde, 1980; Hamburger and Yip, 1984; Oppenheim 1991; CNS: Cui and Harvey, 1995; Cohen-Cory et al., 1996; Ma et al., 1998; Spalding et al., 1998, 2005). Such findings are consistent with the neurotrophic hypothesis (Davies, 1996), which proposes that neurons with axons in target sites compete for limited amounts of target-derived neurotrophic factors, and only responsive neurons that receive sufficient amounts of these factors survive.

Developing neurons with axons en route to targets survive independent of support from target-derived trophic factors. However, studies on cranial sensory neurons and lower motoneurons (Davies et al., 1987; Vogel and Davies, 1991; Mettling et al., 1995; Enokido et al., 1999) suggest that there is a maturational switch to dependency on target-derived factors as axons grow into such targets. Additionally in the PNS, the further axons have to grow the longer it takes for their parent neurons to switch on their trophic dependency (Davies, 1989; Vogel and Davies, 1991). Importantly, in PNS neurons the transition to target dependency is delayed by the same amount of time in vitro as it would be in vivo (Davies et al., 1987; Davies, 1989; Vogel and Davies, 1991), suggesting it is an intrinsic property of those neurons.

A similar phenomenon may occur in the visual system. In chick RGCs, a switch from target independence to dependence has been reported (Rodriguez-Tébar et al.,

Received October 21, 2014; accepted June 23, 2015; First published June 29, 2015.

${ }^{1}$ The authors declare no competing financial interests.

${ }^{2}$ Author Contributions: A.R.H., J.R. designed research; C.M., L.P.G.W., A.K., C.J.LeV, M.R., A.R.H., M.A.P. performed research; C.M., L.P.G.W., C.J.LeV, A.K., M.R., G.S.C., A.S., J.R., A.R.H. analyzed data; A.R.H., J.R., C.M., L.P.G.W., A.S. wrote paper.

${ }^{3}$ This work was funded by the National Health and Medical Research Council (NHMRC; 634347) and NHMRC Senior Research Fellowship to J.R. with additional support from the Western Australia Neurotrauma Research Program (funded through the Road Trauma Trust Account). We thank Louise Cole at the Advanced Microscopy Facility and Donna Lai at the Molecular Biology Facility, Bosch Institute, University of Sydney. We also thank Marissa Penrose-Menz for assistance with figure preparation.

${ }^{*}$ C.M. and L.P.G.W. contributed equally to this work.

Correspondence should be addressed to Alan R. Harvey, School of Anatomy, Physiology, and Human Biology, The University of Western Australia, Perth, WA 6009, Australia. E-mail: alan.harvey@uwa.edu.au.

DOI:http://dx.doi.org/10.1523/ENEURO.0044-14.2015

Copyright (C) 2015 Moses et al.

This is an open-access article distributed under the terms of the Creative Commons Attribution 4.0 International, which permits unrestricted use, distribution and reproduction in any medium provided that the original work is properly attributed.
1989). In rat, RGCs first appear at $\sim \mathrm{E} 13$ and genesis continues until E19/E20 (Reese and Colello, 1992; Rapaport et al., 2004). Soon after differentiation, RGCs begin to extend axons (Waid and McLoon, 1995), almost all of which project to the contralateral SC (Sefton et al., 2004). Axons of first-born RGCs reach the SC at $\sim$ E16.5 (Lund and Bunt 1976; Bunt et al., 1983), a delay of 2-3 d, whereas axons of RGCs born on E18/E19 do not reach the SC until 4-6 d after birth, a delay of 8-9 d (Dallimore et al., 2002). Progressive innervation of the brain by different populations of RGCs as they mature has also recently been described in the mouse (Osterhout et al., 2014). In the rat, early-born RGCs begin PCD before birth whereas late-born RGCs only die between P4 and P6 (Dallimore et al., 2010), thus a switch to target dependency should be revealed by differences in the time course of PCD in early-born versus late-born RGCs.

Previous studies have documented changes in gene expression in developing RGCs defined solely on the basis of the age of the animal from which the cells were obtained (Trimarchi et al., 2007; Wang et al., 2007; Moore et al., 2009). However, because of the prolonged neurogenesis of RGCs in rats, at any given prenatal or postnatal age RGCs are at different stages of maturation, constituting a heterogeneous population (Dallimore et al., 2002, 2010). Thus to more definitively characterize the factors that contribute to the switch to target dependency in maturing RGCs, at different times after birth we analyzed and compared gene expression in neonatal rat RGCs that had been identified and selected purely on the basis of their day of neurogenesis.

RGCs born on E15 or E18 were labeled with pulses of EdU. RGCs were then investigated at different stages of target ingrowth: before axon ingrowth (E18-labeled pups killed at P0 or P1), during ingrowth (E18-labeled pups at P5), and after innervation (E15-labeled pups at P0). EdUpositive $\left({ }^{+}\right)$RGCs were isolated from cryosections using single-cell laser-capture microdissection (LCM) and RNA extracted for qPCR. We selected genes that are either involved in trophic factor signaling or have been implicated in RGC survival and/or axonal outgrowth. Pathwayspecific discriminant analysis was used to compare gene expression profiles between RGCs with axons already in the SC and RGCs with axons still growing toward the SC and other major central target sites. Because the data from the LCM studies suggested changes in BDNF signaling in maturing RGCs, we also compared in vitro the trophic requirements of purified P1 RGCs labeled on either E15 or E18 with BrdU.

\section{Materials and Methods}

\section{Animals}

Time-mated female Wistar rats $(n=10)$ were used for EdU injections and gene expression studies. EdU was used for the in vivo GPCR experiments because the protocols for visualizing BrdU result in RNA degradation, and an earlier pilot study found that it was not possible to capture BrdU-labeled cells with LCM while maintaining RNA integrity. E15 or E18 (day after mating = E0) pregnant rats were anesthetized with isoflurane (4\% induction 
and $2 \%$ maintenance in $20 \% \mathrm{O}_{2} / 80 \% \mathrm{~N}_{2} \mathrm{O}$ ) and injected with $\mathrm{EdU}(20 \mathrm{mg} / \mathrm{kg}$ maternal body weight, i.p.) two times during the day (at 10 A.M. and 3 P.M.) to ensure prolonged bioavailability (Zeng et al., 2010). Procedures were approved by institutional (UWA Animal Ethics Committee) and government (NHMRC) guidelines.

\section{Tissue collection and processing}

Parturition occurred on E22/22.5 (day of birth $=P 0$ ). P0, $\mathrm{P} 1$, or P5 pups were deeply anesthetized with $0.2 \mathrm{ml}$ intraperitoneal pentobarbital sodium (Lethabarb; Virbac) and perfused transcardially with $4 \%$ paraformaldehyde in diethylpyrocarbonate-treated $0.1 \mathrm{M}$ PBS (dPBS). Eyes were harvested immediately after fixation and the cornea and lens removed in dPBS, leaving the eyecup with retina attached. Retinas were postfixed in $4 \%$ paraformaldehyde for $1 \mathrm{~h}$, immersed in $30 \%$ sucrose in dPBS for $1 \mathrm{~h}$, and then into increasing concentrations of Jung Tissue Freezing Medium (Leica Microsystems; 25, 50, 75, and $100 \%$; $1 \mathrm{~h}$ immersion at each stage at $4^{\circ} \mathrm{C}$ ) before being frozen. Eyecups were cryosectioned at $10 \mu \mathrm{m}$ and every second section mounted onto Menzel-Gläser SuperFrost Plus glass slides (usually eight retinal sections per slide), ensuring that the eyecup was positioned so that the central to peripheral retina was represented in every section. Instruments and cryostat surfaces were treated with RNaseZap (Ambion) cleaning solution and $70 \%$ ethanol before use. Sections were stored at $-80^{\circ} \mathrm{C}$ prior to immunohistochemistry and laser capture (see below).

Multiple retinas were allocated to individual groups, each group constituting a biological replicate that gave a distinct sample of microdissected RGCs for mRNA analysis. mRNA analysis experiments were performed in two separate rounds. For an initial pilot LCM experiment we had estimated that 800 RGCs would yield $\sim 8 \mathrm{ng}$ of total RNA (10 pg per neuron); however, when many genes failed to amplify during qPCR it became clear that we had insufficient RNA of necessary quality to perform the desired analysis; thus, a second more extensive experiment was performed to capture a significantly greater number of EdU ${ }^{+}$RGCs. The initial pilot experiment compared five replicate groups of E18 EdU RGCs with five replicate groups of E15 EdU RGCs, both at P0 (E18/P0 and E15/P0 label/killed, respectively). Five retinas, randomly selected from different litters, were pooled to form each replicate group (except for two E15 groups, one of which had three retinas and one had four). The second round of laser capture compared E18 RGCs at P1 (E18/P1, five replicate groups) with E18 at P5 (E18/P5, five replicate groups) and E15 at P0 (E15/P0, three replicate groups). Each of these groups contained RGCs from five different rat pups. For textual clarity, the E15/P0 RGCs now will be described as "target-dependent RGCs," E18/P0 or P1 RGCs as "growing RGCs," and E18/P5 RGCs as "transitional RGCs."

\section{EdU and Brn3a immunohistochemistry}

EdU detection was performed using the Click-iT EdU Alexa Fluor 488 Imaging Kit (Invitrogen). Sections were permeabilized with $0.2 \%$ Triton X-100 (Progen Industries) in dPBS for $30 \mathrm{~min}$, washed with $3 \%$ protease-free BSA (Sigma-Aldrich) in dPBS $(2 \times 5 \mathrm{~min})$, then incubated with
$300 \mu \mathrm{l}$ reaction mixture prepared according to kit directions for $30 \mathrm{~min}$. In the first pilot run, cells were not double labeled with Brn3a to distinguish RGCs, because at PO there are as yet no displaced amacrine cells in the GCL (Perry, 1981). In the more extensive follow-up experiment we also wished to obtain laser-captured E18 RGCs from $\mathrm{P} 5$ retinas at a time when their axons are in the process of innervating the SC; however, at this age potentially $\mathrm{EdU}^{+}$ amacrine cells are now present in the GCL. Thus for all groups in this second series we additionally immunostained retinal sections for Brn3a protein, an established marker for RGCs projecting to the SC (Nadal-Nicolás et al., 2009, 2012). Retinal sections were washed with dPBS $(2 \times 10 \mathrm{~min})$ and incubated overnight at $4^{\circ} \mathrm{C}$ with anti-Brn3a goat primary antibody (AB; Santa Cruz Biotechnology, SC-31984) 1:100 in antibody diluent (10\% normal horse serum and $0.2 \%$ Triton $\mathrm{X}-100$ in $\mathrm{dPBS}$ ). After washes, sections were incubated in donkey antigoat Cy3 (Jackson ImmunoResearch, 705-166-147; 1:200 in antibody diluent) for $2 \mathrm{~h}$.

\section{LCM}

For both the pilot and second GPCR experiments, LCM was undertaken using a Carl Zeiss PALM CombiSystem. Retinal sections were viewed at $20 \times$ magnification; $\mathrm{EdU}^{+}$ cells (first experiment) or $\mathrm{EdU}^{+} / \mathrm{Brn} \mathrm{a}^{+} \mathrm{RGCs}$ (second experiment) were tagged using PALM Robo software and catapulted into a $0.5 \mathrm{ml} \mathrm{PCR}$ tube cap containing $40 \mu \mathrm{l}$ proteinase $\mathrm{K}$ digest buffer (Qiagen). Only those cells that were heavily and evenly labeled for EdU (first experiment) or both EdU and Brn3a (second experiment) were selected. Focus and energy settings were adjusted for each new slide prior to loading the collection cap to ensure a single cell was catapulted with each shot. After catapulting, sections were again checked to ensure single cells had been captured. Approximately 200 cells were dissected into each cap over a period of $1 \mathrm{~h}$ before the cap was transferred to $-80^{\circ} \mathrm{C}$. In the initial experiments $\sim 800$ cells were collected for each of the five E18 replicate groups, and $\sim 1000-1200$ cells for each of the five E15 replicate groups, in which $\mathrm{EdU}^{+} \mathrm{RGCs}$ are more numerous. In the second LCM study, $\sim 26,000$ RGCs were captured, and each replicate of the $10 \mathrm{E} 18$ and three E15 groups contained up to $2000 \mathrm{EdU}^{+} / \mathrm{Brn}^{3} a^{+} \mathrm{RGCs}$. After $\mathrm{LCM}$, microdissected cell samples were stored at $-80^{\circ} \mathrm{C}$ until RNA extraction.

\section{RNA extraction and reverse transcription}

RNA extraction was performed using the Qiagen RNeasy FFPE kit and RNA was converted to CDNA and pre-amplified for qPCR using the Qiagen $\mathrm{RT}^{2}$ PreAMP cDNA synthesis kit. In the initial qPCR experiment, because of the smaller than expected amount of RNA collected, RNA samples could not be quantified to ensure there was equal RNA input amounts in the reverse transcription reaction for each group, thus qPCR data were normalized only to the geometric mean of the reference genes PPIA and RPL10A (Becker et al., 2010). These genes showed a close pattern of expression changes across the groups. In the follow-up LCM study, in which a greater number of RGCs was captured, the concentration 
and integrity of RNA could be quantified using the Agilent RNA 6000 Pico Kit run on an Agilent 2100 Bioanalyzer prior to housekeeper normalization in qPCR; $1 \mathrm{ng}$ total RNA from each sample was reverse transcribed. Although there was still RNA degradation (RNA Integrity Numbers $<8.0$ ) from fixation and the unavoidable and extensive tissue processing prior to laser capture, the amount of RNA was sufficient to perform cDNA synthesis and qPCR. In both the pilot and second follow-up experiment, cDNA was pre-amplified using the Qiagen $\mathrm{RT}^{2}$ PreAMP cDNA synthesis kit for eight cycles.

qPCR

qPCR was performed using Custom Qiagen $\mathrm{RT}^{2}$ Profiler PCR Arrays and Qiagen $\mathrm{RT}^{2}$ SYBR Green ROX FAST Mastermix. Custom PCR arrays contained primers for 90 genes of interest (Table $1^{3}$ ) and three housekeeping genes and three controls to verify PCR performance. A Corbett Rotor-Gene 6000 cycler was programmed with the following cycling settings: $95^{\circ} \mathrm{C}$ for $10 \mathrm{~min}$, followed by 60 cycles of $95^{\circ} \mathrm{C}$ for $15 \mathrm{~s}$, and $60^{\circ} \mathrm{C}$ for $30 \mathrm{~s}$. Fluorescence threshold was fixed within the exponential phase of amplification and was identical for each run. A melting program $\left(0.5^{\circ} \mathrm{C}\right.$ stepwise from 60 to $\left.95^{\circ} \mathrm{C}\right)$ was run after cycling and samples with multiple or abnormal melt peaks or those that crossed the threshold after cycle 45 were excluded from analysis.

\section{Statistical analysis}

In both the first and second qPCR rounds, expression of each gene between conditions was compared using the $\Delta$ Ct method (Livak and Schmittgen, 2001; Pfaffl, 2001; Schmittgen and Livak, 2008). In both rounds, two reference genes (PPIA and RPL10a) were used to normalize expression across groups; the third (HPRT) was not used because of excessive variance. For each gene of interest, comparisons of gene expression across the conditions were performed: growing versus target-dependent RGCs, growing versus transitional RGCs, and transitional versus target-dependent RGCs. For each pairwise comparison, a fold change value was calculated to indicate relative gene expression level and a Student's $t$ test was performed. A $p$ value $<0.05$ was considered statistically significant, and only fold changes $> \pm 2$ were considered. Data are presented as mean fold change.

\section{Discriminant analysis}

To further assess changes in gene expression between groups in the second LCM study, we used discriminant analysis, a multivariate statistical technique used for differentiating groups using multiple quantitative variables. Using JMP software, we calculated two canonical scores that represented all of the variability of the dataset. The canonical scores were then compared between groups to identify significant differences using ANOVA. Differences in individual gene expression were then determined using ANOVA and Tukey post hoc tests.

A first-pass analysis included expression profiles of all 45 genes that were successfully amplified to determine whether there were significant differences between the groups of RGCs at different developmental stages. Hav- ing established differences between the groups in this global analysis, we then performed a more focused analysis to look for differential activation of individual pathways at the different developmental stages. We examined genes implicated in selected pathways related to BDNF signaling as follows: downstream of TrkB via PLCg (BDNF, CAMK1, CAMk2d, CAMk2g, CREB, and PLCg1) and downstream of TrkB via Ras (BDNF, CREB, MAP2k2, MAPk1, and MAPk3). We also examined pathways implicated in neuronal survival and axon elongation: Akt signaling (Akt1, Akt3, Bax, BDNF, and GSK3B) and JAKSTAT signaling (CNTFRa, JAK2, STAT1, and STAT3).

\section{In vitro analysis of trophic dependence}

Nine time-mated female Wistar rats were injected intraperitoneally at $\mathrm{E} 15(n=2)$ or E18 $(n=7)$ with BrdU, $50 \mathrm{mg} / \mathrm{kg}$ maternal body weight, three times during the day (at 9 A.M. and 1and 5 P.M.). At P1, pups were killed with sodium pentobarbital (Lethabarb) and eyes were removed. Retinas were dissected from eyes and pooled into dPBS, then dissociated using the MACS neural dissociation kit (Miltenyi Biotec) according to manufacturer's instructions. RGCs were isolated using the MACS RGC Isolation kit (Miltenyi Biotec), following standard depletion and selection protocols. Cells were resuspended in defined serum-free growth medium (Ullian et al., 2004; modified from Bottenstein and Sato, 1979). Neurobasal media contained B27 supplement, triiodothyronine, transferrin, progesterone, sodium selenite, $n$-acetyl cysteine (SigmaAldrich), $2 \mathrm{~mm}$ L-glutamine, $1 \mathrm{~mm}$ sodium pyruvate (Life Technologies), $5 \mu \mathrm{g} / \mathrm{ml}$ insulin, and $10 \mu \mathrm{m}$ forskolin (Sigma), with or without $50 \mathrm{ng} / \mathrm{ml}$ BDNF (PeproTech). RGCs were seeded onto poly-D-lysine (70 kDa, $10 \mu \mathrm{g} / \mathrm{ml}$; Sigma) and mouse type-1 laminin (Sigma)-coated 8-well culture slides (Falcon; BD).

Purified RGC populations were fixed after $1 \mathrm{~d}$ or $2 \mathrm{~d}$ in culture (analogous to P2 and P3 in vivo). For immunostaining, cells were fixed with $4 \%$ paraformaldehyde, washed, and double labeled with anti- $\beta$-III tubulin antibody (TUJ1 clone, rabbit; Covance PRB-435P, 1:4000) with goat anti rabbit Cy3 secondary (Jackson ImmunoResearch $111166047,1: 400$ ), both for $30 \mathrm{~min}$ at room temperature, followed by 30 min $2 \mathrm{M} \mathrm{HCl}$ treatment for $30 \mathrm{~min}$ at $37^{\circ} \mathrm{C}$. Cells were then incubated overnight with BrdU antibody (mouse; Roche 11170376001, 1:100) in diluent containing 4\% NGS, 3\% BSA, and 0.3\% Triton X-100, washed, and incubated for $2 \mathrm{~h}$ at room temperature with goat anti-mouse FITC secondary antibody (Cappel 55521; 1:100). Slides were coverslipped in Dako Fluorescent mounting medium.

Data were obtained from four separate culture preparations of purified E15 RGCs and five preparations of purified E18 RGCs. Two wells were counted for each culture for each condition ( \pm BDNF, $24 \mathrm{~h}$ or $48 \mathrm{~h}$ survival). Slides were examined by light and multichannel fluorescent microscopy using an Olympus BX50 microscope equipped with a motorized stage $(x, y, z)$, and a digital, color top-mounted camera (Qlmaging), and linked to a computer with Stereo-Investigator software (V10.0; MBF Bioscience). Each well of the culture slide was outlined at 
Table 1 Gene primers in the Qiagen Custom $\mathrm{RT}^{2}$ Profiler PCR Array CAPR11291R

\begin{tabular}{|c|c|c|c|}
\hline Gene & Function & RefSeq no. & $\mathrm{FC}$ \\
\hline Adcyap 1 & Stimulates cAMP production; upregulated over development (Boeshore et al., 2004; Wang et al., 2007) & NM_016989 & - \\
\hline Akt1 & $\begin{array}{l}\text { Downstream of PI3K; critical in neurotrophin-mediated growth and survival (Kaplan and Miller, 2000; Perkinton et al., 2002; } \\
\text { Campos et al., 2003) }\end{array}$ & NM_033230 & $\uparrow$ \\
\hline Akt3 & Downstream of PI3K; critical in neurotrophin-mediated growth and survival (as above) & NM_031575 & $\uparrow$ \\
\hline ApoE & Involved in CNTF signaling, regulated over development (Fischer, 2012) & NM_138828 & $\downarrow$ \\
\hline $\operatorname{Arg} 1$ & $\begin{array}{l}\text { Downstream from cAMP in survival and regeneration; critical in overcoming myelin inhibition; regulated over development } \\
\text { (Cai et al., 2002; Moore and Goldberg, 2011) }\end{array}$ & NM_017134 & - \\
\hline ATF3 & $\begin{array}{l}\text { Transcription factor; interacts with CREB and c-JUN; upregulated after injury, promotes regeneration (Seijffers et al., 2006; Moore } \\
\text { and Goldberg, 2011) }\end{array}$ & NM_012912 & - \\
\hline Bad & Pro-apoptotic protein (Isenmann et al., 2003; Wilson and Di Polo, 2012) & NM_022698 & - \\
\hline Bax & Pro-apoptotic protein (as above) & NM_017059 & $\uparrow$ \\
\hline$B c / 2$ & Anti-apoptotic protein; necessary for neuronal survival; overexpression reduces PCD (Brunet et al., 2001; Campos et al., 2003) & NM_016993 & $<2$ \\
\hline$B c / 2 / 1$ & Anti- or pro-apoptotic protein depending on splice variant (as above) & NM_031535 & - \\
\hline$B c / 2 / 11$ & Pro-apoptotic protein; downstream of FOXO transcription factors (as above) & NM_022612 & - \\
\hline$B D N F$ & Promotes RGC survival; axon branching; synaptogenesis (Numakawa et al., 2010) & NM_012513 & $\uparrow$ \\
\hline CAMK1 & Phosphorylates CREB; prolongs ERK activation; regulates axon growth (Lonze and Ginty, 2002; Perkinton et al., 2002; Jiao et al., 2005) & NM_134468 & $\downarrow$ \\
\hline CAMK2d & $\begin{array}{l}\text { Phosphorylates CREB; prolongs ERK activation; regulates axon growth and dendritic architecture; involved in depolarization-induced } \\
\text { survival (as above) }\end{array}$ & NM_012519 & $\hat{\imath}$ \\
\hline CAMK2g & $\begin{array}{l}\text { Phosphorylates CREB; prolongs ERK activation; regulates axon growth, dendritic architecture, neurite length; involved in } \\
\text { depolarization-induced survival (as above) }\end{array}$ & NM_133605 & $\downarrow$ \\
\hline Casp8 & Apoptotic factor; expressed after injury; mediates apoptosis through FOXO1 (Brunet et al., 2001; O’Driscoll et al., 2006; Johnson et al., 2009) & NM_022277 & - \\
\hline Casp9 & Apoptotic factor; activates effector caspases; involved in PCD (as above) & NM_031632 & - \\
\hline Cdc42 & $\begin{array}{l}\text { Rho family GTPase; positive regulator of actin dynamics, microtubule formation, growth cone formation, and axon elongation; acts in } \\
\text { opposition to RhoA (Zhou and Snider, 2006; Major and Brady-Kalnay, 2007; Hausott et al., 2009) }\end{array}$ & NM_171994 & $\uparrow$ \\
\hline Cdh1 & Adhesion factor; regulates axon growth and patterning (Konishi et al., 2004) & NM_031334 & - \\
\hline CNTFR & Receptor for CNTF; promotes growth and survival (Yip and So, 2000; Lingor et al., 2008) & NM_001003929 & $\uparrow$ \\
\hline CREB1 & Transcription factor; critical for survival and growth signaling (Lonze and Ginty, 2002; Moore and Goldberg, 2011) & NM_031017 & $\uparrow$ \\
\hline$D C C$ & Guidance factor; receptor for netrin-1; involved in guidance toward optic disk (Koeberle and Bähr, 2004; Erskine and Herrera, 2007) & NM_012841 & - \\
\hline$D C X$ & Microtubule-associated protein; growth promoting (Blackmore et al., 2010) & NM_053379 & - \\
\hline DSCAM & Guidance factor; involved in self-avoidance (Fuerst et al., 2008,2009) & NM_133587 & $<2$ \\
\hline EFNA2 & Ephrin A2 ligand; involved in inhibition; expressed in development and after axotomy in adult (O'Leary and Wilkinson, 1999; Cang et al., 2008) & NM_001168 670 & - \\
\hline EGFR & Receptor for EGF; involved in myelin inhibition; required for development of some CNS regions (Hannila and Filbin, 2008; Hausott et al., 2009) & NM_031507 & - \\
\hline ELK1 & Transcription factor; regulates cell cycling; pro-survival effects (Hausott et al., 2009) & XM_001055949 & - \\
\hline EphA4 & Receptor for Ephrin A and B; involved in inhibition (O'Leary and Wilkinson, 1999; Reber et al., 2004; Lindqvist et al., 2010) & NM_001162 411 & $<2$ \\
\hline Fos & Involved in regulation of TrkB expression (Chang et al., 2004; Park et al., 2004) & NM_022197 & $<2$ \\
\hline FOXO3 & Pro-apoptotic transcription factor; inhibited by neurotrophin signaling via Akt and SGK (Brunet et al., 2001) & NM_001106 395 & - \\
\hline Gap43 & Protein required for axon growth (Schaden et al., 1994) & NM_017195 & - \\
\hline GHR & Growth hormone receptor; pro-survival effects on developing RGCs via CREB (Sanders et al., 2008) & NM_017094 & $\downarrow$ \\
\hline GSK3B & $\begin{array}{l}\text { Influences cytoskeleton assembly; involved in pro-apoptotic signaling; apoptotic function inhibited by Akt (Brunet et al., 2001; } \\
\text { Tokuoka et al., 2002; Alabed et al., 2010) }\end{array}$ & NM_032080 & $\uparrow$ \\
\hline HAND1 & Transcription factor, required for sympathetic neuronal survival (Doxakis et al., 2008) & NM_021592 & $<2$ \\
\hline HAND2 & Transcription factor, required for sympathetic neuronal survival (as above) & NM_022696 & - \\
\hline IGF-1R & Growth factor receptor; promotes RGC survival and growth (Goldberg et al., 2002) & NM_052807 & $\hat{\imath}$ \\
\hline II6R & Cytokine receptor; promotes RGC survival and growth (Cao et al., 2006; Moore and Goldberg, 2011) & NM_017020 & $\uparrow$ \\
\hline IL6st & Part of the IL6R complex; promotes RGC survival and growth (as above) & NM_001008 725 & $\downarrow$ \\
\hline JAK1 & $\begin{array}{l}\text { Component of JAK/STAT signaling cascade; involved in signaling via IL6R, CNTFR, and GHR; regulated in development } \\
\text { (Park et al., 2004; Wang et al., 2007) }\end{array}$ & NM_053466 & $<2$ \\
\hline JAK2 & Component of JAK/STAT signaling cascade (Park et al., 2004) & NM_031514 & - \\
\hline Jun & Transcription factor; involved in apoptosis, growth, and regeneration (Lu et al., 2003; Tedeschi, 2012) & NM_021835 & - \\
\hline KLF4 & Transcription factor; inhibits axon growth, regulated in development (Moore et al., 2009) & NM_053713 & $<2$ \\
\hline KLF6 & Transcription factor; promotes axon growth (Veldman et al., 2007; Moore et al., 2009) & NM_031642 & - \\
\hline KLF7 & Transcription factor; promotes axon outgrowth (as above) & NM_001108 800 & $\hat{\imath}$ \\
\hline KLF9 & Transcription factor; inhibits axon outgrowth (as above) & NM_057211 & - \\
\hline L1CAM & Cell adhesion molecule, upregulated in axon regeneration (Fischer et al., 2004) & NM_017345 & - \\
\hline LIFR & $\begin{array}{l}\text { IL6 class cytokine receptor; neurotrophic factor; promotes survival and growth in RGCs (Goldberg et al., 2002; Moore } \\
\text { and Goldberg, 2011; Fischer, 2012) }\end{array}$ & NM_031048 & - \\
\hline LINGO1 & Part of Nogo receptor complex (Mi et al., 2004; Fu et al., 2008; Hannila and Filbin, 2008) & NM_001100 722 & - \\
\hline MafK & Transcription factor; upregulated after axotomy (Fischer et al., 2004) & NM_145673 & - \\
\hline MAP2k1 & Major neurotrophin signaling pathway (Atwal et al., 2000; Gao et al., 2003; Hausott et al., 2009; Johnson et al., 2009) & NM_031643 & - \\
\hline MAP2k2 & Major neurotrophin signaling pathway (as above) & NM_133283 & $\hat{\imath}$ \\
\hline MAPK1 & Kinase involved in MAPK signaling (Kaplan and Miller, 2000; Reichardt, 2006) & NM_053842 & $<2$ \\
\hline MAPK14 & $\begin{array}{l}\text { Kinase involved in both apoptosis and survival signaling; downstream phosphorylation of CREB; possibly involved in } \\
\text { neurite outgrowth (as above) }\end{array}$ & NM_031020 & - \\
\hline MAPKЗ & Kinase involved in MAPK signaling (as above) & NM_017347 & $\uparrow$ \\
\hline MAPK8 & $\begin{array}{l}\text { Kinase involved in pro-apoptotic signaling; inhibits Akt, downstream in p75NTR apoptotic signaling; activates c-Jun; regulates microtubule } \\
\text { formation (Kaplan and Miller, 2000; Roux and Barker, 2002; Zhou and Snider, 2006) }\end{array}$ & XM_341399 & $<2$ \\
\hline MAPK9 & Kinase involved in pro-apoptotic signaling; involved in developmental apoptosis (Kuan et al., 1999; Le-Niculescu et al., 1999) & NM_017322 & $<2$ \\
\hline mTOR & Kinase; controls protein synthesis required for axon growth; downstream of PI3K (Park et al., 2008) & NM_019906 & $\downarrow$ \\
\hline NFATc3 & Transcription factor; involved in axonal growth; neurotrophins alter activity (Zhou and Snider, 2006; Moore and Goldberg, 2011) & NM_001108447 & $<2$ \\
\hline NFATc4 & Transcription factor; involved in axonal growth; neurotrophins alter activity (as above) & NM_001107264 & $<2$ \\
\hline Ngfr & $\begin{array}{l}\text { p75NTR; low-affinity neurotrophin receptor; pro-neurotrophin receptor; pro- or anti-apoptotic depending on conditions (Kaplan } \\
\text { and Miller, 2000; Roux and Barker, 2002) }\end{array}$ & NM_012610 & - \\
\hline Nptx2 & Role in synaptic plasticity (Fischer et al., 2004) & NM_001034 199 & - \\
\hline Nrxn1 & Involved in synapse formation (Barker et al., 2008) & NM_021767 & $\hat{\imath}$ \\
\hline
\end{tabular}


Table 1 Gene primers in the Qiagen Custom RT² Profiler PCR Array CAPR11291R

\begin{tabular}{|c|c|c|c|}
\hline Gene & Function & RefSeq no. & FC \\
\hline Nrxn2 & Involved in synapse formation (as above) & NM_053846 & - \\
\hline Ntrk2 & TrkB; receptor for BDNF (Atwal et al., 2000; Kaplan and Miller, 2000) & NM_012731 & $<2$ \\
\hline Optn & Involved in axonal transport, regulated in development (Wang et al., 2007) & NM_145081 & $\uparrow$ \\
\hline$P d e 4 b$ & Enzyme responsible for cAMP hydrolysis; inhibited by neurotrophin signaling (Gao et al., 2003; Hannila and Filbin, 2008) & NM_017031 & - \\
\hline PKCcd & $\begin{array}{l}\text { Kinase involved in PI3K and p75NTR/NgR signaling; regulates MAPK activity (Reichardt, 2006; Zhou and Snider, 2006; } \\
\text { Major and Brady-Kalnay, 2007) }\end{array}$ & NM_133307 & - \\
\hline PLCg1 & $\begin{array}{l}\text { Phospholipase activated through TrkB; extends MAPK signaling; increases intracellular } \mathrm{Ca}^{2+} \text { (Segal, 2003; Zhou and } \\
\text { Snider, 2006; Numakawa et al., 2010) }\end{array}$ & NM_013187 & $\downarrow$ \\
\hline POU4F1 & $\begin{array}{l}\text { Transcription factor Brn3a; involved in dendritic branching and architecture (Weishaupt et al., 2005; Badea et al., 2009; } \\
\text { Voyatzis et al., 2012) }\end{array}$ & XM_341372 & $\downarrow$ \\
\hline POU4F2 & Transcription factor Brn3b; involved in cell-fate determination; critical for RGC differentiation, involved in axonal development (as above) & NM_134355 & - \\
\hline Psip1 & Transcription factor; regulates expression of growth-associated genes; involved in dendritic arborization (Zhao et al., 2008) & NM_175765 & - \\
\hline PTEN & Phosphatase; converts $\mathrm{PIP}_{3}$ to $\mathrm{PIP}_{2}$; inhibits Akt and downstream signaling (Park et al., 2008) & NM_031606 & $\uparrow$ \\
\hline Ptk7 & Transcription factor; downstream in PI3K and MAPK pathways; involved in BDNF-induced survival (Chang et al., 2004) & NM_001106 889 & - \\
\hline Rac1 & $\begin{array}{l}\text { Rho family GTPase; involved in growth cone mechanics; inhibits RhoA; involved in nasal-temporal crossing (Pearse, 2004; Schiller, 2006; } \\
\text { Major and Brady-Kalnay, 2007) }\end{array}$ & NM_134366 & $\uparrow$ \\
\hline RelA & NFkB transcription factor; involved in axonal growth and survival; activated by p75NTR (Moore and Goldberg, 2011) & NM_199267 & - \\
\hline RhoA & $\begin{array}{l}\text { GTPase; activates ROCK triggering growth cone collapse; binds to p75NTR (Park et al., 2005; Lingor et al., 2008; Mi, 2008; } \\
\text { Hausott et al., 2009) }\end{array}$ & NM_057132 & $\uparrow$ \\
\hline Rock1 & Kinase; downstream of RhoA in mediating growth cone collapse (as above) & NM_031098 & - \\
\hline Rps6 & Ribosomal protein; growth and survival promoting (Sun and He, 2010) & NM_017160 & - \\
\hline Rps6ka1 & $\begin{array}{l}\text { Phosphorylates ribosomal Protein s6; activates STATs, CREB; involved in MAPK survival signaling (Lonze and Ginty, 2002; } \\
\text { Chang et al., 2004; Koeberle and Bähr, 2004) }\end{array}$ & NM_031107 & - \\
\hline Rps6ka2 & Phosphorylates ribosomal Protein s6; activates STATs, CREB; involved in MAPK survival signaling (as above) & NM_057128 & $<2$ \\
\hline Rps6kb1 & Phosphorylates ribosomal Protein s6; downstream of Akt and mTOR (Manning and Cantley, 2007; Park et al., 2008) & NM_031985 & - \\
\hline Rtn4r & $\begin{array}{l}\text { Part of NgR-p75NTR signaling complex; mediates inhibitory signaling dependent on cAMP levels and Arg1 activity (Cai et al., 2002; } \\
\text { Schwab, 2004; Fu et al., 2008) }\end{array}$ & NM_053613 & - \\
\hline SGK1 & Kinase; involved in PI3K pathway, similar to Akt; inhibits pro-apoptotic factors, e.g., FOXO3 (Brunet et al., 2001) & NM_019232 & - \\
\hline socs3 & Negative regulator of JAK/STAT signaling; knock-out improves regeneration (Sun and He, 2010; Hellström et al., 2011; Fischer, 2012) & NM_053565 & - \\
\hline Sort1 & Pro-neurotrophin receptor; complexes with p75NTR; pro-apoptotic (Jansen et al., 2007; Teng et al., 2010) & NM_031767 & $<2$ \\
\hline SOX11 & Transcription factor; increases expression of growth-associated molecules (Veldman et al., 2007; Moore and Goldberg, 2011) & NM_053349 & - \\
\hline STAT1 & Activated by STAT3 via JAK/STAT cascade (Moore and Goldberg, 2011; Tedeschi, 2012) & NM_032612 & $\uparrow$ \\
\hline STAT3 & Component of JAK/STAT signaling cascade; pro-survival signaling (as above) & NM_012747 & $\uparrow$ \\
\hline Stk24 & Kinase; critical for axon regeneration in cultured CNS neurons (mst3B; Lorber et al., 2009) & NM_001127 494 & $\uparrow$ \\
\hline Tnfrsf19 & TROY; takes place of p75NTR with LINGO and NgR (Park et al., 2005; Hisaoka, 2006; Mi, 2008) & Unigene: Rn.202731 & - \\
\hline PPIA & Housekeeping gene (commonly used rat housekeeping gene in laboratory) & NM_017101 & - \\
\hline Rp/10a & Housekeeping gene (Hong Cai et al., 2007) & NM_031065 & - \\
\hline HPRT & Housekeeping gene (Vázquez Chona and Vazquez, 2004) & NM_012583 & - \\
\hline
\end{tabular}

Brief function, relevant citations, and RefSeq number are listed for each gene. Arrows in the right column indicate a $> \pm 2$ relative fold change $(\mathrm{FC})$ in gene

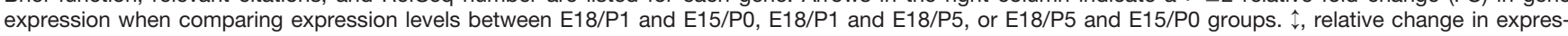
sion, either up or down, depending on pairwise comparison; see Fig. $2 \mathrm{~B}$ for details. $<2$, genes with a change in expression $< \pm 2 ;-$, genes that failed to amplify in one or more samples, or amplification was evident but only after cycle 45 and therefore discounted.

its border using a $4 \times$ objective (bright field) using the contour mapping feature in the Stereo-Investigator software. The sampling area consisted of 100 uniform but random counting frames $(550 \times 330 \mu \mathrm{m})$, which were calculated using the Systematic Random Sampling layout feature (total area sampled $\sim 18 \mathrm{~mm}^{2}, \sim 25 \%$ of the surface area). All $\beta$-III-tubulin ${ }^{+}$cells within each frame were counted using fluorescent light (TRITC filter) and classified according to either the presence or absence of prominent $\beta$-III-tubulin ${ }^{+}$processes. Incorporation of BrdU into RGC nuclei was classified subjectively by a single operator and an assessment made of the nuclear area containing BrdU (either no BrdU, $<50 \%$ of nuclei area expressing BrdU, or $>50 \%)$. Each $\beta$-III-tubulin ${ }^{+}$RGC was therefore counted and classified based on the presence of absence of processes and BrdU content within the nucleus. Results were tallied by the software and exported to Microsoft Excel for further analysis. Data were quantified from four E15 and 5 E18 cultures (two wells counted for each culture for each condition).

To examine BDNF expression in late-born RGCs, in two additional purified RGC cultures from litters labeled at E18 with BrdU, RGCs were maintained for $24 \mathrm{~h}$ or $48 \mathrm{~h}$ in Neurobasal media without recombinant BDNF. At $24 \mathrm{~h}$ or
$48 \mathrm{~h}$, cultures were fixed in $4 \%$ paraformaldehyde, and after blocking (10\% NGS, $0.2 \%$ Triton X-100 for $30 \mathrm{~min}$ ) cultures were immunostained with antibodies to BDNF (rabbit; BiosensisR-172-20 or Santa Cruz Technology SC$546)$ or $\beta$-III-tubulin (Covance PRB-435P, 1:400) in blocking buffer for $1 \mathrm{~h}$ followed by incubation in secondary antibodies (1 h, anti-rabbit Cy3). Cultures were then reacted for BrdU as described above and coverslipped.

\section{Anti-BDNF antibody specificity}

To confirm that both the BDNF antibodies bound specifically to BDNF we performed an absorption control test using recombinant BDNF protein (Human BDNF; PeproTech). First, BDNF protein was eluted in $2 \times$ Laemmli buffer [250 mu Tris, 10\% (v/v) glycerol, 4\% (w/v) SDS, 2\% (v/v) $\beta$-mercaptoethanol, $0.005 \%$ (w/v) bromophenol blue (Sigma-Aldrich)] in double-deionized water (DDW; pH 6.8), separated by SDS-PAGE (Mini-PROTEAN TGX Stain-Free Precast Gels; Bio-Rad) and transferred to nitrocellulose membrane (Trans-Blot Turbo Mini Nitrocellulose Transfer Pack; Bio-Rad). Recombinant proteins were detected by Western blot using 3\% (w/v) skim milk powder in TBS-T [100 mm Tris, $154 \mathrm{~mm} \mathrm{NaCl,} 0.1 \%$ (v/v) Tween 20, in DDW, $\mathrm{pH}$ 7.5] blocking buffer, antibodies to BDNF (rabbit; Bio- 

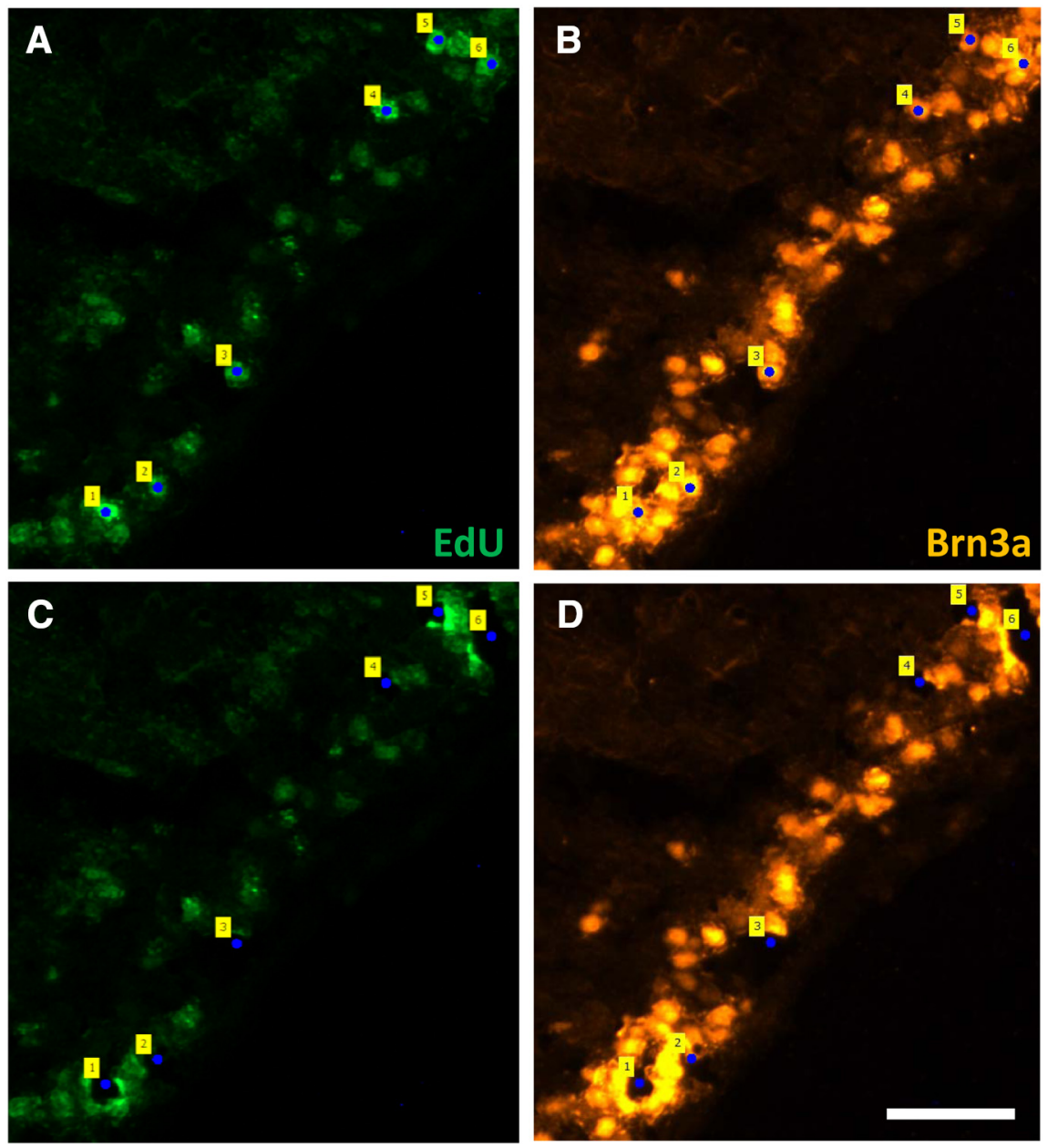

Figure 1 LCM isolates individual RGCs from tissue sections; neurons are identified by their birthdate. EdU and Brn3a-stained retinal section from a pup that received an E18 EdU injection and was perfused at P1. $\boldsymbol{A}, \boldsymbol{B}$, Section before LCM stained for EdU $(\boldsymbol{A})$ and Brn3a (B); DL RGCs were tagged (numbers). C, $\boldsymbol{D}$, Section after LCM, stained for EdU (C) and Brn3a (D); tags show spaces left following catapulting of DL cells. Scale $=50 \mu \mathrm{m}$.

sensis R-172-20, 1:500 or Santa Cruz Biotechnology, SC-546; 1:500) and $\alpha$-rabbit-HRP secondary antibody (1:10,000 dilution; Pierce Scientific). Proteins were visualized by chemiluminescence (Immun-Star; Bio-Rad) using the ChemiDoc system (Bio-Rad). In the absorption control, the anti-BDNF antibody $(1 \mu \mathrm{g}$, rabbit; Biosensis $\mathrm{R}-172-20)$ was incubated with $10 \mu \mathrm{g}$ of BDNF diluted in $100 \mu \mathrm{l}$ blocking agent and incubated overnight at $4^{\circ} \mathrm{C}$. The pre-absorbed primary antibody was then used to immunostain purified RGC cultures using the protocol described above.

\section{Results}

qPCR of laser-captured RGCs before, during, and after target innervation

In retinas used for $\mathrm{LCM}, \mathrm{EdU}^{+}$cells were seen in the GCL and other layers of the retina. In E15-injected EdU groups, $\mathrm{EdU}^{+}$cells in the $\mathrm{GCL}$ were found in all regions of the retina, whereas in E18 EdU groups there were far fewer double-labeled (DL) $\mathrm{EdU}^{+} / \mathrm{Brn3a}^{+}$neurons. These RGCs were mostly located in the periphery, consistent with previous reports (Reese and Colello, 1992; Dallimore et al., 2002). LCM using the PALM DuoFlex CombiSystem successfully catapulted individual cells from retinal sections. Figure 1 shows retinal sections stained for EdU and Brn3a, with DL cells tagged before and after laser catapulting.

Two separate LCM studies were performed. In the initial pilot experiment we captured almost 9000 RGCs, giving at least 800 RGCs per replicate group; however, with this number of RGCs RNA and CDNA yields were below the sensitivity of the NanoDrop and Agilent Bioanalyzer 6000 Nano Kits. Nonetheless we proceeded to qPCR analysis of the entire cDNA stock obtained in this first experiment. Several genes exhibited at least a fourfold change in mRNA expression levels between targetdependent and growing RGCs, although due to failure of amplification in some samples none of these changes reached statistical significance. Genes encoding BDNF, NFATc3, Adcyap1, EphA4, and STAT3 all appeared to be upregulated in growing RGCs compared with targetdependent RGCs, whereas ApoE and NFATc4 were down- 
regulated. Importantly, BDNF transcript levels exhibited by far the greatest reduction between growing and targetdependent RGCs, consistent with PCR data from the second LCM study.

The initial LCM work was needed to establish optimal protocols for identifying gene changes in individually isolated postnatal RGCs. Based on this first study, we next used LCM to accumulate approximately three times as many RGCs (25,871 in total). In this second experiment only Brn3a ${ }^{+} \mathrm{EdU}^{+} \mathrm{RGCs}$ were selected for capture. Up to 2000 RGCs were used in each replicate qPCR group. In the second laser-capture experiment, of the initial 90 genes selected for amplification (Table 1), 45 genes were consistently amplified in sufficient groups to allow for statistical comparison. These were as follows: Akt1, Akt3, ApoE, Bax, Bcl2, BDNF, CAMK1, CAMK2d, CAMK2g, Cdc42, CNTFRa, CREB1, DSCAM, EphA4, Fos, GHR, GSK3B, HAND1, IGF-1R, II6R, IL6st, JAK1, KLF4, KLF7, MAP2k2, MAPK1, MAPK3, MAPK8, MAPK9, mTOR, NFATc3, NFATc4, Nrxn1, Ntrk2, Optn, PLCg1, POU4F1, PTEN, Rac1, RhoA, Rps6ka2, Sort1, STAT1, STAT3, Stk24 (Fig. 2A).

Growing RGCs showed altered expression of a significant number of genes when compared with either targetdependent or transitional RGCs. The 30 genes with a $> \pm 2$-fold change in expression between the various groups are displayed in Figure 2B. Comparison between growing and target-dependent RGC groups revealed a statistically significant relative increase in expression of IGF-1R and CREB1, and a significant relative decrease in expression of CAMK2g and PLCg mRNAs in growing RGCs. Comparatively large fold increases in mRNA levels in growing RGCs were also noted for CNTFRa, BDNF, GSK3B, Akt3, and PTEN. Fewer genes differed when comparing growing versus transitional, and transitional versus target-dependent, RGC groups. CAMK1 expression was significantly lower in transitional compared with target-dependent RGCs (Fig. 2B), but overall the extent of any fold change was generally less in these comparisons. Exceptions were large fold increases in Akt3, GSK3B, and CNTFRa gene expression and a more than 10-fold decrease in neurexin 1 gene expression in growing versus transitional RGCs, and increased expression of IGF-1R, Stk24, and IL6R in transitional versus target-dependent RGCs.

\section{Discriminant analysis and significant differences between growing and target-dependent RGCs}

To further assess changes in gene expression between groups, we used discriminant analysis, a multivariate statistical technique used for differentiating groups using multiple quantitative variables. Discriminant scores confirmed that all replicates could be allocated with $100 \%$ confidence to their appropriate group/developmental stage based on the pattern of gene expression. An ANOVA comparing the canonical scores revealed significant differences between conditions and Tukey post hoc tests confirmed that each condition was significantly different from the other two (growing vs target-dependent $p<0.0001$; transitional vs target-dependent: $p<0.0001$; growing vs transitional: $p=0.023$; Fig. $2 C$ ). Genes that contributed most to these differences were BDNF, CAMK1, Akt1, and Akt3.

\section{Pathway analysis and intracellular signaling}

To further examine the potential involvement of signaling pathways in RGCs during the transition to target dependence, discriminant analysis was performed on genes known to be associated with particular growth or survival-associated pathways, focusing on systems downstream of BDNF and TrkB (Fig. 3), and the CNTF receptor complex (Fig. 4).

BDNF signaling via TrkB activates three distinct pathways, all partially covered by our gene arrays (Fig. $3 B, C$ ). Genes that are components of the CAMK downstream pathway (Fig. $3 A, B$, green) were significantly different between growing, transitional and target-dependent RGC groups. Genes in the MAPK downstream pathway (Fig. $3 A, B$, blue) were also significantly different, with expression of MAPK isoforms increased in growing compared with nongrowing RGCs. A significant difference in the expression profile of the Akt signaling pathway (Fig. $3 A, B$, pink) was seen, primarily attributed to an increase in expression of Akt isoforms in growing RGCs (Fig. 3C). Additionally, the growing and target-dependent RGC groups showed a significantly different gene expression profile for at least some factors involved in CNTF signaling, with a peak of CNTFRa and downstream Stat1 and Stat3 expression in actively growing, late-born RGCs (Fig. 4). Transcripts for IL6st (also known as gp130) also appear to be more prevalent, particularly in transitional RGCs.

\section{Tissue culture: RGC survival in the presence or absence of BDNF}

Data were obtained from four separate culture preparations of purified P1 RGCs previously labeled with BrdU on either E15 or E18. Each of the 72 wells was initially plated with $\sim 15,000$ cells. Counting areas were randomly sampled (see Materials and Methods). Independent of the BrdU label, in total $\sim 35,000 \beta$-III-tubulin ${ }^{+}$RGCs were counted. Based on these counts we estimated that, in the presence of BDNF, on average 18.4 and $14.3 \%$ of initially plated RGCs remained viable at 24 and $48 \mathrm{~h}$, respectively, compared with 11.4 and $6.2 \%$ in the absence of BDNF. Expression of clearly defined, multiple $\beta$-III-tubulin ${ }^{+}$processes was also affected by neurotrophic support (Fig. 5); irrespective of birthdate, with BDNF 65.5 and $52.9 \%$ of surviving RGCs expressed processes at 24 and $48 \mathrm{~h}$, compared with 41.5 and $33.4 \%$ in the absence of this neurotrophin.

On the critical issue of viability of RGCs identified by birthdate, we calculated the average number $( \pm$ SEM) of $\mathrm{E} 15$ or $\mathrm{E} 18 \mathrm{BrdU}^{+} \mathrm{RGCs}$ (BrdU label in $>50 \%$ of the nucleus) in the presence or absence of BDNF at 24 and $48 \mathrm{~h}$. There was no change in E18 RGC counts in the two conditions, indicating that these late-born cells did not require exogenous BDNF for survival; however, there was a significant (*Mann-Whitney $U$ test, $p<0.05$ ) loss of E15 RGCs between 24 and 48 hours (Fig. 6). Consistent with this, in addition to the overall loss of viable $\beta$-III-tubulin ${ }^{+}$ 
A

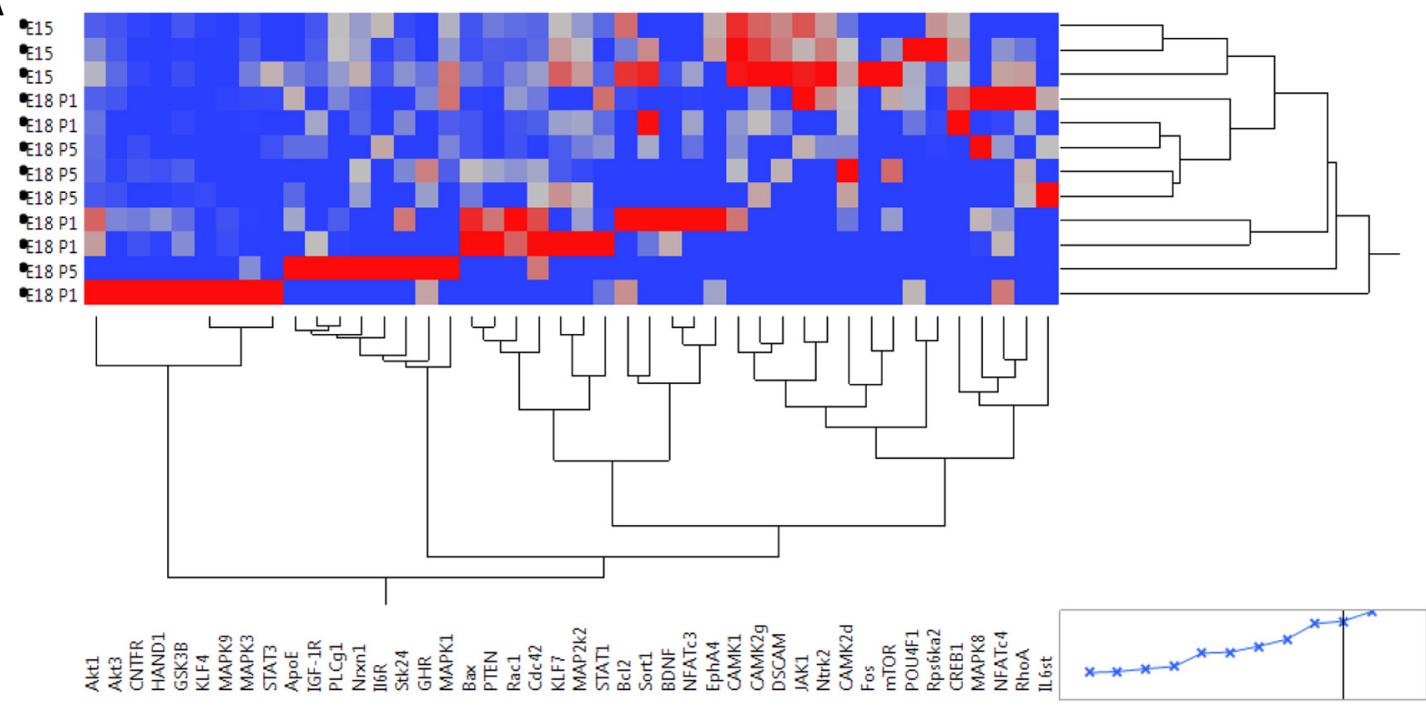

B

B E18 P1/E15 P0

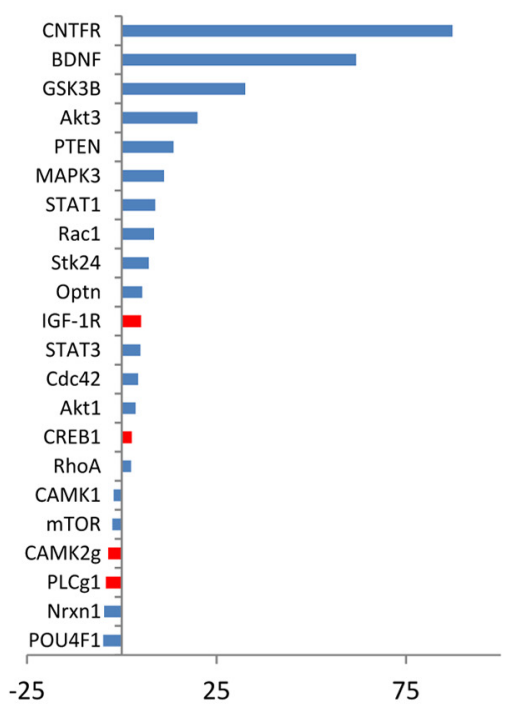

E18 P1/E18 P5

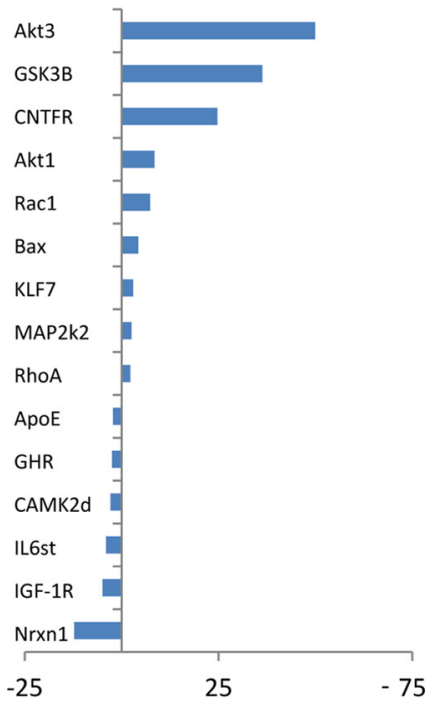

E18P5/E15 PO

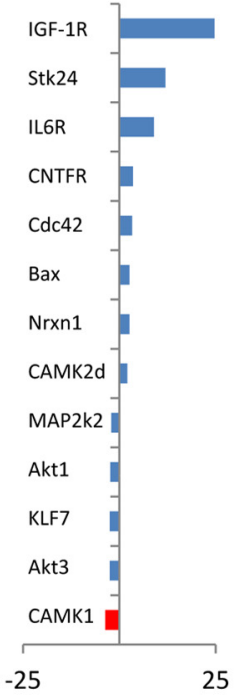

C

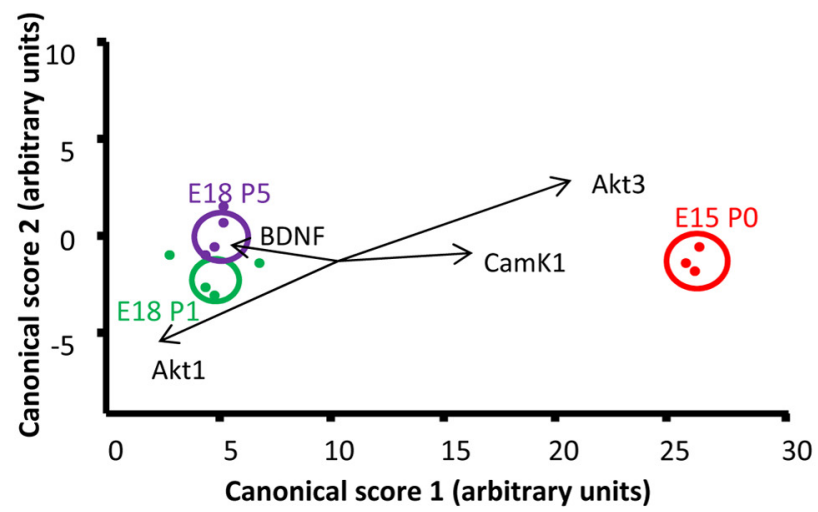

Figure $2 \boldsymbol{A}$, Heat map and cluster analysis for all genes with reliable PCR amplification. $\boldsymbol{B}$, Pairwise comparisons between actively growing (E15/P0), target-independent (E18/P1), and transitional (E18/P5) RGCs, showing all genes with > \pm 2 -fold change. Significant differences are shown in red. $\boldsymbol{C}$, Plots show canonical scores 1 ( $x$-axis) and 2 ( $y$-axis) from a multivariate discriminant analysis of overall gene expression levels $\left(2^{-\Delta \mathrm{CT}}\right)$. The two canonical scores represent $100 \%$ of the variance. Axes represent arbitrary units of SD. Circles represent the $95 \%$ confidence region to contain the true mean of the treatment groups. Black lines show the coordinate direction (for simplicity, only selected individual gene expression levels are shown here) in canonical space. Note that the length of 
continued

the lines is not representative of effect size due to the multidimensional nature of the analysis. Comparisons are made on canonical scores using ANOVA with Tukey's post hoc test: E15/P0 versus E18/P1: $p<0.0001$ (Canonical 1); E15/P0 versus E18/P5: $p<0.0001$ (Canonical 1); E18/P5 versus E18/P1: $p=0.0203$ (Canonical 2).

RGCs at $48 \mathrm{~h}$, the proportion of these surviving $\beta$-IIItubulin ${ }^{+}$RGCs that were born on E15 was decreased, and the proportion of $\mathrm{E} 18 \mathrm{BrdU}^{+} \mathrm{RGCs}$ increased, in $48 \mathrm{~h}$ cultures that lacked BDNF (Table 2). Many surviving E18 RGCs continued to express processes (Fig. 5B,C), thus the distinction between early-born and late-born RGCs was even greater when only analyzing process-bearing RGCs. Without BDNF, between 24 and $48 \mathrm{~h}$ the proportion of surviving $\beta$-III-tubulin ${ }^{+}$E15 RGCs in the cultures was reduced by almost half, whereas the proportion of E18 RGCs increased from 1.5 to $3.6 \%$ (Table 2).

In the second series of in vitro studies, E18 BrdUlabeled RGCs were isolated and cultured for either $24 \mathrm{~h}$ or $48 \mathrm{~h}$ in the absence of BDNF. After fixation, RGCs were immunostained with antibodies to BDNF (Fig. 5D-G). Immunostaining was substantially reduced when antibodies were pre-absorbed with recombinant BDNF protein (data not shown). Although BDNF positivity was not entirely restricted to the $\mathrm{BrdU}^{+}$population (many surviving neurons would be from outside the labeling window), BrdU ${ }^{+}$ RGCs were immunopositive for BDNF, with qualitatively greater staining at $48 \mathrm{~h}$ compared with $24 \mathrm{~h}$.

\section{Discussion}

In the developing rat, a significant proportion of RGCs die at the time their axons are growing into and innervating central target sites such as the SC (Dallimore et al., 2002, 2010). Using custom qPCR arrays to quantify gene expression in birth-dated neonatal RGCs isolated by LCM, we have, for the first, time obtained snapshots of gene expression in maturing CNS neurons in situ. This novel methodology allowed an unprecedented investigation of the expression status of identified RGCs, at different stages of maturation in vivo, without confounding issues associated with analysis of whole retinal tissue or analysis of gene expression in vitro on cultured or cell-sorted RGCs. We have identified subtle differences in gene expression in RGCs that (1) are growing independently toward their target, (2) have axons in the process of target ingrowth, and (3) have completed ingrowth and now require central targets for trophic support. These differences, discussed in detail below, include the downregulation of endogenous BDNF expression as RGCs innervate central targets, along with changes in expression of genes involved in signaling pathways downstream of TrkB. There were also maturational changes in responsiveness to cytokines and other growth factors. Although further work is needed to validate and clarify these results, the approach utilized in this study should eventually assist in unraveling the complex factors involved in circuit formation during visual system development.

\section{The switch to target dependency in developing RGCs: BDNF}

We obtained two lines of evidence suggesting that RGCs switch to a particular dependency on targetderived BDNF as their axons enter retinorecipient sites in the brain. The first comes from our qPCR array lasercapture experiments, both of which demonstrated that BDNF mRNA expression in growing late-born RGCs was considerably greater than in RGCs with axons already in central targets. While previous work has shown that BDNF is expressed by RGCs (Cohen-Cory et al., 1996; Frost et al., 2001; Rohrer et al., 2001; Vecino et al., 2002), and that RGCs express the cognate TrkB receptor (Cohen-Cory et al., 1996; Suzuki et al., 1998; Rohrer et al., 2001; Vecino et al., 2002; Marshak et al., 2007), the clearly defined developmentally regulated change in BDNF transcript levels in different birth-dated RGC cohorts reported here is a new finding. Importantly, growing CNS-derived RGCs also exhibited increased expression of transcripts associated with survival- and growth-related pathways downstream of TrkB. These included mRNA for signaling proteins downstream of TrkB-Ras, which promote survival and neurite outgrowth through MAPK phosphorylation of CREB (Mayr and Montminy, 2001), and lead to upregulation of a wide range of anti-apoptotic genes, including BDNF itself (Korsmeyer, 1999; Mayr and Montminy, 2001). In actively growing RGCs, pathways downstream of TrkB-Akt were also activated, consistent with a role for Akt1 in inhibiting pro-apoptotic factors and promoting survival in response to neurotrophic stimulation (Korsmeyer, 1999; Brunet et al., 2001).

TrkB expression has also been reported to be developmentally regulated (Rickman and Brecha, 1995; Ugolini et al., 1995), but we were unable to detect any change. Previous studies in rat have shown that exogenous application of BDNF or the related neurotrophin NT-4/5 temporarily protects P4/P5 RGCs after central target ablation (Cui and Harvey 1995; Spalding et al., 1998), and BDNF supports the survival of cultured neonatal RGCs (this study; cf. Johnson et al., 1986; Meyer-Franke et al., 1995; Cohen-Cory et al., 1996), which it should be noted have also been axotomized during the process of isolation and cell culture. Furthermore, BDNF is expressed in the SC and is retrogradely transported by RGCs (Ma et al., 1998; von Bartheld, 1998; Frost et al., 2001; Rohrer et al., 2001; Marotte et al., 2004). Our new data are thus consistent with the proposal that BDNF has an important role in maintaining cell-autonomous RGC survival before axonal ingrowth into central targets. Such an interpretation echoes the autocrine (and/or paracrine) supply of neurotrophins that occurs in peripheral sensory neuron populations prior to target innervation (Wright et al., 1992; Davies, 1996). 
A

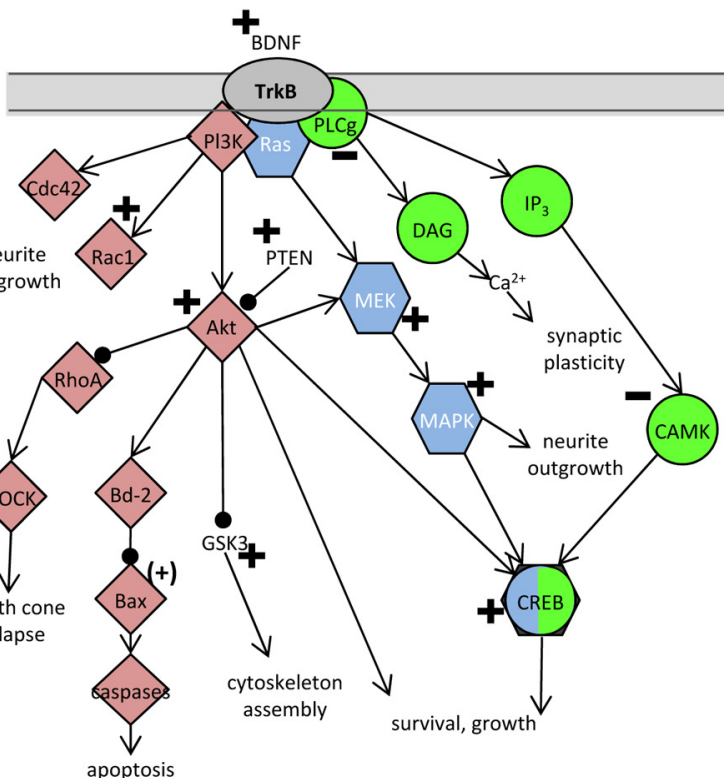

BDNF

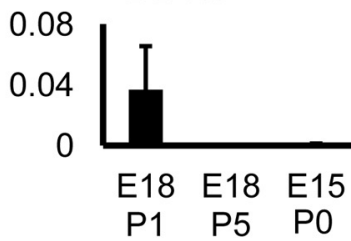

Akt1

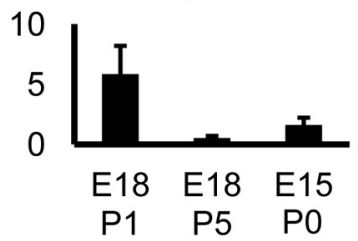

B
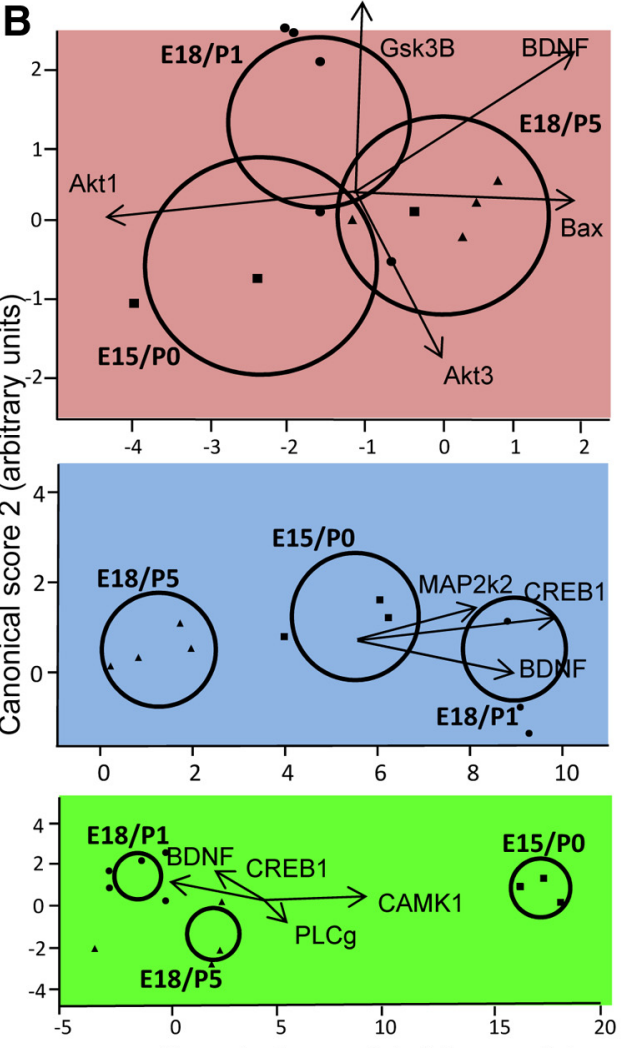

Canonical score 1 (arbitrary units)
Akt3

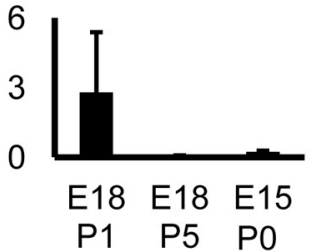

Bax

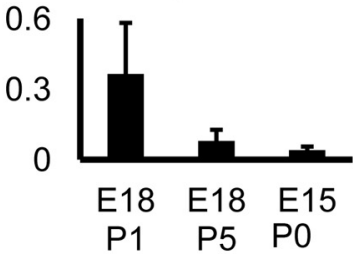

GSK3B

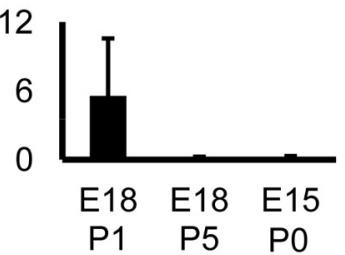

PLCg

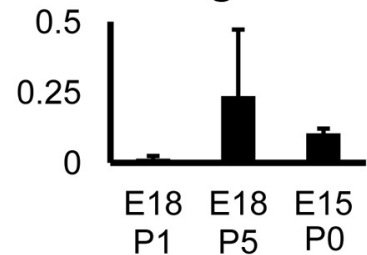

Map2k2

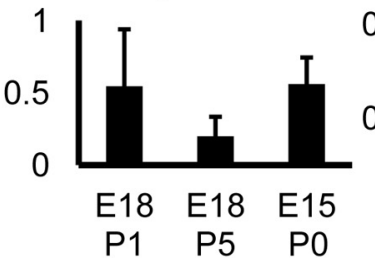

CREB1

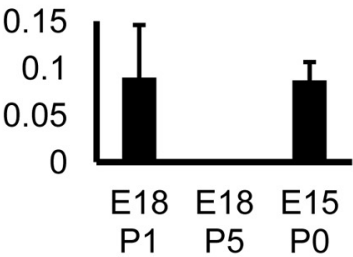

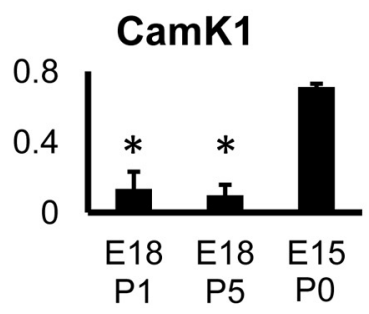

Figure 3 Analysis of genes in pathways downstream of BDNF signaling. $\boldsymbol{A}$, Diagram showing the main pathways analyzed. Note that some genes in the diagram did not show changes, or were not analyzed, but are included for context. $\boldsymbol{B}$, Plots show canonical scores 1 ( $x$-axis) and 2 ( $y$-axis) from a multivariate discriminant analysis of a subset of genes within specific pathways downstream of BDNF. Colors are used to identify distinct pathways, but in some cases genes are common to more than one pathway. The two canonical scores represent $100 \%$ of the variance. Axes represent arbitrary units of SD. Circles represent the $95 \%$ confidence region to contain the true mean of the treatment groups. Black lines show the coordinate direction (for simplicity, only selected individual gene expression levels are shown here) in canonical space. Note that the length of the lines is not representative of effect size due to the multidimensional nature of the analysis. Comparisons are made on canonical scores using ANOVA with Tukey's post hoc test: via PICg: E15/P0 versus E18/P1: $p<0.0001$; E15/P0 versus E18/P5: $p<0.0001 ; \mathrm{E} 18 / \mathrm{P} 5$ versus E18/P1: $p<0.0016$. Via Ras: E18/P1 versus E18/P5: $p<0.0001$; E15P0 versus E18/P5: $p=0.0008$; E18/P1 versus E15/P0: $p=0.0026$. Via GSK3b: E18/P5 versus E15/P0: $p=0.0483$; E18/P5 versus E18/P1: $p=0.1186$; E18/P1 versus E15/P0: $p=0.6579$. $\boldsymbol{C}$, Histograms showing mean relative expression level of individual genes ( \pm SEM) for each group. Significant differences are indicated with an asterisk. 
A

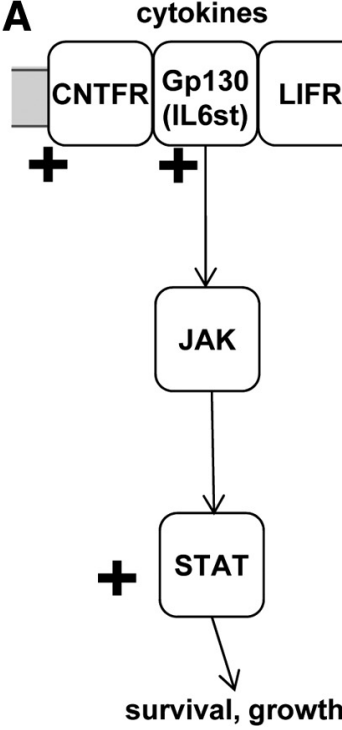

\section{Stat1}

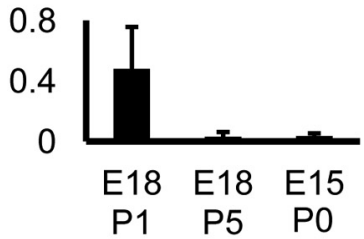

B

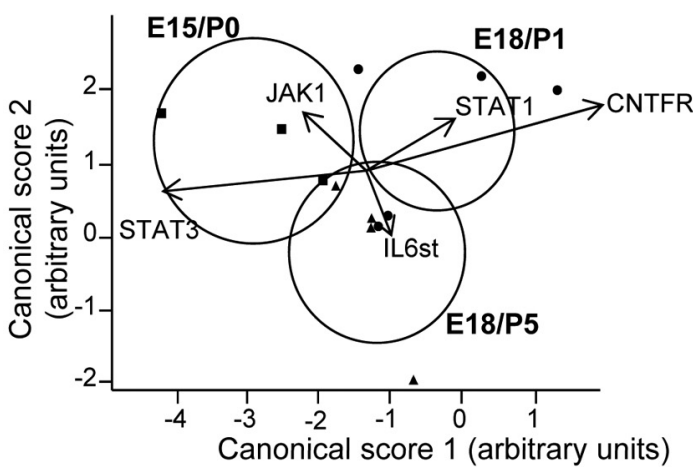

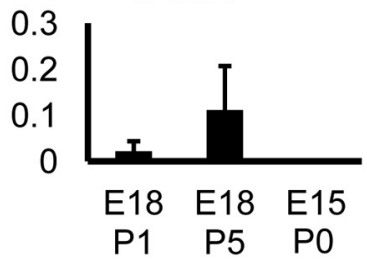

CNTFR

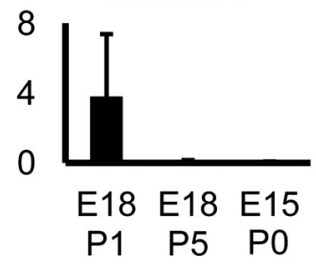

Stat3

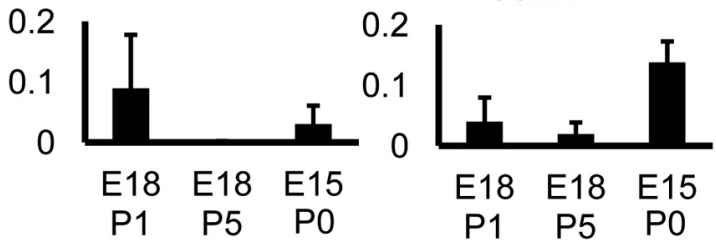

Figure 4 Analysis of genes in pathways downstream of CNTF signaling. $\boldsymbol{A}$, Diagram showing the main pathways analyzed. Note that some genes in the diagram did not show changes, or were not analyzed, but are included for context. $\boldsymbol{B}$, Plots show canonical scores 1 ( $x$-axis) and 2 ( $y$-axis) from a multivariate discriminant analysis of a subset of genes downstream of CNTF. The two canonical scores represent $100 \%$ of the variance. Axes represent arbitrary units of SD. Circles represent the $95 \%$ confidence region to contain the true mean of the treatment groups. Black lines show the coordinate direction (for simplicity, only selected individual gene expression levels are shown here) in canonical space. Note that the length of the lines is not representative of effect size due to the multidimensional nature of the analysis. Comparisons are made on canonical scores using ANOVA with Tukey's post hoc test: E18/P1 versus E15/P0: $p=0.0177$; E18/P5 versus E15/P0: $p=0.1261$; E18/P1 versus E18/P5: $p=0.4446$.

Our second line of evidence comes from the in vitro data showing that the dependency of purified P1 RGCs on exogenous BDNF for survival are related to their date of birth and thus their axon growth status at the time of isolation. In the absence of exogenous BDNF the number of cultured $\mathrm{E} 15 \mathrm{BrdU}^{+} \mathrm{RGCs}$ declined by $>50 \%$ between 24 and $48 \mathrm{~h}$ while late-born E18 $\mathrm{BrdU}^{+}$RGCs survived for at least $48 \mathrm{~h}$. Additionally, E18 RGCs maintained expression of endogenous BDNF throughout their time in culture, consistent with these cells still being target independent. Thus temporal differences in the acquisition of target dependency and onset of PCD in early-born versus late-born RGCs are maintained in culture and in the absence of in vivo environmental signals, suggesting that such differences may be intrinsically determined (cf. Davies et al., 1987; Vogel and Davies 1991; Davies, 1996).

Despite these various observations suggesting BDNF via TrkB acts as a survival factor for developing RGCs, the number of RGCs is not reduced in BDNF knock-out mice (Cellerino et al., 1997), and RGCs survive the postnatal period in mice lacking TrkB (Rohrer et al., 2001). Depletion of TrkB using fusion proteins does increase the peak rate of RGC death in neonates but does not alter final cell number (Pollock et al., 2003). After early gene deletion there may be compensation (via NT-4/5 actions and/or cytokine expression, or signaling through other receptors) that maintains RGC viability; however, conditional Cremediated deletion of BDNF as neurons mature also did not affect RGC viability or myelination (Rauskolb et al., 2010). Note, however, that in these mice some BDNF $(5 \%$ of control) was still measurable by ELISA in cerebral cortex, but BDNF levels were not reported for retinal tissue.

It is difficult to reconcile these various observations to our current, and previously published, findings. TrkB expressed in the absence of BDNF does not trigger neuronal death and is thus not a "dependence receptor" (Nikoletopoulou et al., 2010). However, lack of ligand-induced kinase activity in TrkB receptors may alter numerous downstream pathways that indirectly mediate RGC death. RGCs do express p75 and/or the related Troy, both members of the tumor necrosis factor receptor family that 

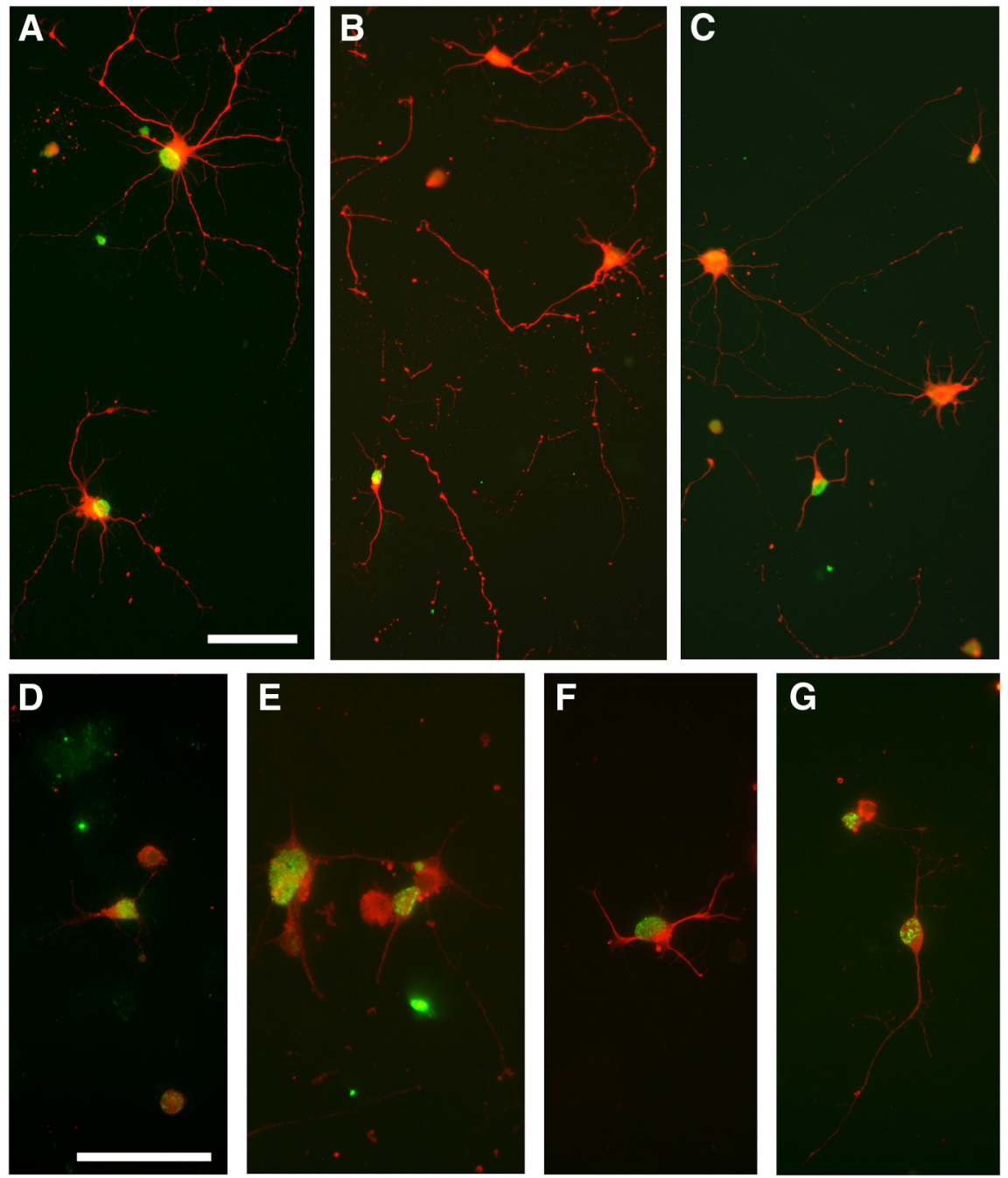

Figure 5 Examples of BrdU-labeled (green), $\beta$-III-tubulin ${ }^{+}$(red) RGCs purified at P1 and examined after $48 \mathrm{~h}$ in culture in the presence $(\boldsymbol{A})$ or absence $(\boldsymbol{B}, \boldsymbol{C})$ of BDNF. $\boldsymbol{A}$, Process-bearing, BrdU ${ }^{+}$E15 RGCs are evident at $48 \mathrm{~h}$ in the presence of BDNF. $\boldsymbol{B}, \boldsymbol{C}$, Absence of BDNF resulted in the overall loss of cultured RGCs and reduction in neurite expression; however, E18 RGCs continued to survive and many expressed processes. Note the fragmented neurites from loss of cells between 24 and 48 h. D-G, E18 RGCs cultured without BDNF immunostained with a BDNF antibody. $\boldsymbol{D}$, Twenty-four hour culture. $\boldsymbol{E}-\mathbf{G}$, Forty-eight hour culture. Scale bars: $50 \mu \mathrm{m}$.

possess an intracellular death domain (Mandemakers and Barres, 2005; Ahmed et al., 2006). Perhaps the well described survival effects of either BDNF or NT-4/5 on neonatal RGCs in vitro, or after injury in vivo, are related to altered expression of p75/Troy and TrkB. Yet numerous studies have documented prosurvival effects of BDNF and NT-4/5 in the normal uninjured rodent visual system; application of BDNF to the SC increased RGC survival (Ma et al., 1998), and RGC loss was reduced after intravitreal NT-4/5 injection (Cui and Harvey, 1995). Excess "target-derived" BDNF also prevented the retraction of the normally transient ipsilateral retinotectal pathway (Isenmann et al., 1999). Coinjection of blocking antibodies to BDNF and NT-4/5 in the SC in neonatal rats significantly increased RGC death, as did injection of these same antibodies into the retina, although it is important to note that this increase was considerably less after intraretinal antibody application, which is clearly to be ex- pected if only late-born not yet target-dependent RGCs were affected (Spalding et al., 2004). Finally, Carpenter et al. (1986) and Spalding et al. (2004) described the extensive loss of neonatal RGCs after kainic acid lesions in the SC, a technique thought to cause loss of target neurons in the SC without concomitant axonal injury.

\section{The switch to target dependency in developing RGCs: other growth factors}

Expression of cytokine signaling-related transcripts was also significantly different between RGCs at different stages of target ingrowth. Actively growing RGCs expressed relatively higher levels of CNTFRa mRNA, a subcomponent of the cytokine receptor (Stahl and Yancopoulos, 1994), and its downstream effectors STAT1 and STAT3, known to promote survival and growth (Peterson et al., 2000; Park et al., 2004; Ng et al., 2006). There was also increased expression in transitional and growing RGCs of IL6st, another 


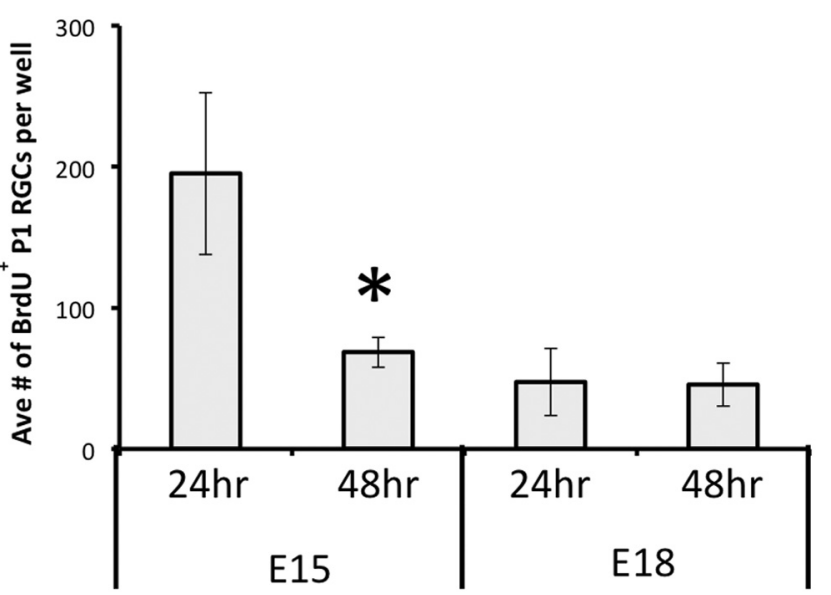

Figure 6 The mean number $( \pm$ SEM) per well of E15 or E18 BrdU-labeled, $\beta$-III-tubulin immunopositive P1 RGCs after either $24 \mathrm{~h}$ or $48 \mathrm{~h}$ in vitro, in the absence of BDNF in the culture medium. Note the significant (asterisk, Mann-Whitney $U$ test, $p<0.05)$ loss of E15 RGCs between 24 and $48 \mathrm{~h}$, but the numbers of E18 RGCs remained unchanged.

subcomponent of the cytokine receptor, and IL6R. It has been reported that exogenous CNTF does not support the survival of RGCs in vitro (Meyer-Franke et al., 1995) or P4/P5 RGCs in vivo (Spalding et al., 2005). However, intraocular application of leukemia inhibitory factor did reduce RGC death to some extent after early SC ablation (Cui and Harvey, 1995). Given the very small population of late-born RGCs, without information about birth date any positive effects of cytokines would be less obvious within the overall RGC population. It is worth noting here that in the adult rat CNTF is a powerful driver of RGC survival and long-distance axonal regeneration (Fischer, 2012; Harvey et al., 2012).

There was significantly greater expression of IGF-1R in growing versus target-dependent RGCs, and relatively greater expression of this receptor in transitional RGCs. IGF-1 is known to have protective effects on neonatal (Gutiérrez-Ospina et al., 2002) and adult (Kermer et al., 2000) RGCs, and IGF-1R expression is necessary for the expression of neurites from adult RGCs in vitro (Dupraz et al., 2013). Note that signaling through this receptor also involves PI3-K and Akt pathways, the latter consistently upregulated in growing RGCs (Fig. 3; Kermer et al., 2000). Transitional RGCs also appeared to express greater levels of the kinase Stk24, also known as MST3b, implicated in the regrowth of adult RGC axons (Lorber et al., 2009).

Table 2 Proportion of surviving, birth-dated RGCs in the presence or absence of BDNF, 24 and $48 \mathrm{~h}$ after plating

\begin{tabular}{lcccc}
\hline & \multicolumn{2}{c}{ E15 BrdU } & \multicolumn{2}{c}{ E18 BrdU } \\
& $24 \mathrm{~h}$ & $48 \mathrm{~h}$ & $24 \mathrm{~h}$ & $48 \mathrm{~h}$ \\
All $\beta$-III-tubulin $^{+}$RGCs & & & & \\
With BDNF $^{\text {No BDNF }}$ & $28.0 \%$ & $28.2 \%$ & $1.5 \%$ & $2.3 \%$ \\
& $24.2 \%$ & $16.9 \%$ & $1.5 \%$ & $3.3 \%$ \\
Process-bearing RGCs & & & & \\
With BDNF & $37.0 \%$ & $38.8 \%$ & $1.4 \%$ & $2.8 \%$ \\
No BDNF & $34.0 \%$ & $20.0 \%$ & $1.5 \%$ & $3.6 \%$ \\
\hline
\end{tabular}

Not all transcripts for prosurvival proteins were more abundant in actively growing RGCs. Expression of genes encoding proteins downstream of TrkB via PLCg, a pathway implicated in moderating survival in response to synaptic interactions and neuronal activity (Tao et al., 1998; Ming et al., 1999; Reichardt, 2006), was reduced presumably because these actively growing RGCs had not yet formed synaptic connections. In this regard, there was a large fold difference between growing and transitional RGCs in expression of transcripts for the presynaptic protein neurexin 1 (Fig. 2B); this is to be expected given that this protein is needed during the process of synaptogenesis (Barker et al., 2008). Finally, we detected increased levels of pro-apoptotic Bax and GSK-3B mRNA, although the concomitantly increased levels of Akt might inhibit the function of these two proteins (Tokuoka et al., 2002; Zhou and Snider, 2006; Alabed et al., 2010). Downregulation of Akt when RGC axons reach their target could provide a rapid and sensitive mechanism for regulating RGC death.

\section{Interpretation of gene expression: RGCs at a transitional stage of target dependency}

In comparing growing (E18/P1) to transitional (E18/P5) RGCs, many of the differences in gene expression were similar to those found for growing versus target-dependent RGCs. Significant differences were also detected between transitional and target-dependent RGCs using multivariate analysis, although such differences were fewer, with generally lower fold changes. Expression of transcripts for proteins in the PLCg pathway was reduced in target-dependent compared with transitional RGCs, including significantly lower levels of CAMK1 mRNA expression. Perhaps the effects of this activity-dependent survival pathway become more important as RGCs begin the process of target innervation.

\section{The development of retina-to-brain connectivity}

During visual system development, BDNF also acts as a terminal arborization factor and promotes the formation and stabilization of synapses (Hu et al., 2005; Marshak et al., 2007). The high level of BDNF we observed in actively growing RGCs seems to conflict with findings that delivering BDNF to the axons of developing RGCs causes long-distance axon extension to cease and triggers collateral arborization and synapse formation (Cohen-Cory and Fraser, 1995). However, in development at least, BDNF can be delivered to the maturing retina without impeding long-distance RGC axon extension (Lom et al., 2002; Cohen-Cory et al., 2010). Perhaps the effect of BDNF on RGC axon outgrowth during development depends on whether it activates TrkB receptors in the axon terminal or the cell body (Lom et al., 2002; Cohen-Cory et al., 2010; Park and Poo, 2013). Alternatively, our new data also pointed to developmental changes in RGC sensitivity to cytokines and other factors, such as insulin-like growth factors. Such factors acting as intermediaries en route to targets could facilitate/promote axonal growth in concert with the role of BDNF in sustaining RGC viability.

Although our experiments did not determine the cause of BDNF downregulation in RGCs as they transition to 
dependence on target-derived trophic support, we can speculate on some of the relevant candidates identified in our expression screen. One possible candidate is the transcription factor CREB, a known driver of BDNF transcription, which is transiently switched off in RGCs in transition and may thus signal a change in transcriptional targets. In this context our initial qPCR suggested that there may be altered expression of members of the NFAT transcription factor family, important in mediating neurotrophin signaling during initial axonal growth (Graef et al., 2003). In addition numerous transcription factors and epigenetic processes including DNA methylation, histone modifications, and microRNA binding could be responsible for developmental changes in BDNF expression (Chen et al., 2003; Numakawa et al., 2010; Zheng et al., 2012; Karpova, 2014; Varendi et al., 2014). Many of these regulatory mechanisms are activity dependent and can direct the mRNA to different locations within the neuron, thus influencing protein function.

Maturational changes in post-translational processing of BDNF may also be important. ProBDNF is cleaved to mature BDNF and these different forms influence RGC axonal growth state via direct and indirect mechanisms (Cohen-Cory et al., 2010). Mature BDNF preferentially activates TrkB, directly promoting survival and axonal growth, whereas proBDNF binds to the p75NTR-sortilin receptor complex to promote apoptosis, or to the p75NTR-NgR-LINGO complex to inhibit neurite outgrowth (Mandemakers and Barres, 2005). Furthermore, the form of BDNF may indirectly change the growth state of RGCs by influencing the outcome of Eph receptor signaling as RGC axons innervate the target. ProBDNF association with p75/TROY (Marler et al., 2010) suppresses EphA-mediated arborization (Marler et al., 2010; Poopalasundaram et al., 2011), but mature BDNF signaling has the reverse effect, promoting branching via the association of the EphA receptor with TrkB (Marler et al., 2008, 2010; for review, see Cohen-Cory et al., 2010). The complex interaction of BDNF and Eph receptor signaling raises the intriguing possibility that downregulation of BDNF expression in developing RGCs may be necessary to enable retinotopic mapping in response to precisely regulated levels of target-derived BDNF (Goodhill and Richards, 1999; Feldheim et al., 2000; Marotte et al., 2004).

\section{Technical considerations}

The experiments reported here are, to our knowledge, the first to compare mRNA expression in identified, birthdated CNS neurons using LCM. The use of BrdU in vivo to help define the spatial-temporal maturation of birth-dated olfactory sensory neurons has recently been reported (Rodriguez-Gil et al., 2015), although this group did not use LCM to isolate individual neurons for gene expression profiling. As detailed in the Results, we encountered several technical issues associated with undertaking GPCR on RGCs captured from fixed retinal sections that had been processed for EdU and Brn3a. Despite the collection of over 25,000 individual RGCs to provide RNA for qPCR, RNA degradation from necessary fixation and IHC proto- cols likely resulted in the failed amplification and variability seen for some genes in the panel. In addition, the variance we often found between samples may reflect a number of real biological variables. Although our estimates here apply to the time required to reach the SC, RGC axons also grow into other targets including the lateral geniculate nucleus and other visual brain regions en route. This, together with delivery of EdU over several hours, may contribute to the variability observed, especially in the transitional E18/P5 cohort, even within identified RGCs of similar but not identical birthdates. Finally, as discussed above, protein function can be altered by post-transcriptional and post-translational processing, as well as by subtle changes to intracellular localization, which are not captured by our qPCR data. This may explain why some genes, such as some Bcl-2 family members, showed no clear-cut changes in expression during the process of target innervation. In future studies it will clearly be of interest to investigate protein expression and epigenetic changes in microdissected CNS neurons identified by day of neurogenesis.

\section{Conclusion}

Single-cell laser microdissection is a powerful tool for assessing gene expression in individual cells in situ. To our knowledge this method has not previously been used to obtain snapshots of gene expression in developing mammalian neurons specifically identified by their day of neurogenesis, at a defined state of in vivo maturation. Such an approach presents technical challenges; nonetheless we have been able to show that gene expression in rat RGCs born on a particular day is correlated with their developmental stage of axonal outgrowth and target innervation. Thus studies that define developmental changes in gene expression based solely on the postconception age of the animal may not give an accurate representation of gene expression changes across development and beyond. While further work is needed to clarify and extend the present work, our data suggest that the transition to target dependency in neonatal rat RGCs is linked to the downregulation of endogenous BDNF expression and altered signaling in downstream pathways, as well as changes in responsiveness to cytokines and perhaps other growth factors. We hypothesize that the combined effects of decreased responsiveness to axogenic factors and decreased intraretinal BDNF expression allows TrkB expressing RGCs to become more sensitive to target-derived BDNF, which is important for the onset of local arbor formation and for the establishment and stabilization of ordered retinotectal connectivity.

\section{References}

Ahmed Z, Suggate EL, Brown ER, Dent RG, Armstrong SJ, Barrett LB, Berry M, Logan A. 2006. Schwann cell-derived factor-induced modulation of the NgR/p75NTR/EGFR axis disinhibits axon growth through CNS myelin in vivo and in vitro. Brain 129:1517-1533. CrossRef Medline

Alabed YZ, Pool M, Ong Tone S, Sutherland C, Fournier AE. 2010. GSK3beta regulates myelin-dependent axon outgrowth inhibition through CRMP4. J Neurosci 30:5635-5643. CrossRef Medline 
Atwal JK, Massie B, Miller FD, Kaplan DR. 2000. The TrkB-Shc site signals neuronal survival and local axon growth via MEK and PI3-kinase. Neuron 27:265-277. Medline

Badea TC, Cahill H, Ecker J, Hattar S, Nathans J. 2009. Distinct roles of transcription factors Brn3a and Brn3b in controlling the development, morphology, and function of retinal ganglion cells. Neuron 61:852-864. CrossRef Medline

Barker AJ, Koch SM, Reed J, Barres BA, Ullian EM. 2008. Developmental control of synaptic receptivity. J Neurosci 28:8150-8160. CrossRef Medline

Becker C, Hammerle-Fickinger A, Riedmaier I, Pfaffl M. 2010. mRNA and microRNA quality control for RT-qPCR analysis. Methods 50:237-243. CrossRef Medline

Blackmore MG, Moore DL, Smith RP, Goldberg JL, Bixby JL, Lemmon VP. 2010. High content screening of cortical neurons identifies novel regulators of axon growth. Mol Cell Neurosci 44:43-54. CrossRef Medline

Boeshore KL, Schreiber RC, Vaccariello SA, Sachs HH, Salazar R, Lee J, Ratan RR, Leahy P, Zigmond RE. 2004. Novel changes in gene expression following axotomy of a sympathetic ganglion: $A$ microarray analysis. J Neurobiol 59:216-235. CrossRef Medline

Bottenstein JE, Sato GH. 1979. Growth of a rat neuroblastoma cell line in serum-free supplemented medium. Proc Natl Acad Sci USA 76:514-517. Medline

Brunet A, Datta SR, Greenberg ME. 2001. Transcription-dependent and -independent control of neuronal survival by the PI3K-Akt signaling pathway. Curr Opin Neurobiol 11:297-305. Medline

Bunt SM, Lund RD, Land PW. 1983. Prenatal development of the optic projection in albino and hooded rats. Dev Brain Res 6:149168. CrossRef

Cai D, Deng K, Mellado W, Lee J, Ratan RR, Filbin MT. 2002. Arginase I and polyamines act downstream from cyclic AMP in overcoming inhibition of axonal growth MAG and myelin in vitro. Neuron 35:711-719. Medline

Campos CBL, Bédard P-A, Linden R. 2003. Selective involvement of the $\mathrm{PI} 3 \mathrm{~K} / \mathrm{PKB} / \mathrm{bad}$ pathway in retinal cell death. J Neurobiol 56: 171-177. CrossRef Medline

Cang J, Wang L, Stryker MP, Feldheim DA. 2008. Roles of ephrin-As and structured activity in the development of functional maps in the superior colliculus. J Neurosci 28:11015-11023. CrossRef Medline

Cao Z, Gao Y, Bryson JB, Hou J, Chaudhry N, Siddiq M, Martinez J, Spencer T, Carmel J, Hart RB, Filbin MT. 2006. The cytokine interleukin- 6 is sufficient but not necessary to mimic the peripheral conditioning lesion effect on axonal growth. J Neurosci 26:55655573. CrossRef Medline

Carpenter P, Sefton AJ, Dreher B, Lim W-L. 1986. Role of target tissue in regulating the development of retinal ganglion cells in the albino rat: Effects of kainate lesions in the superior colliculus. $J$ Comp Neurol 251:240-259. CrossRef Medline

Cellerino A, Carroll P, Thoenen H, Barde Y-A. 1997. Reduced size of retinal ganglion cell axons and hypomyelination in mice lacking brain-derived neurotrophic factor. Mol Cell Neurosci 9:397-408. CrossRef Medline

Chang SH, Poser S, Xia Z. 2004. A novel role for serum response factor in neuronal survival. J Neurosci 24:2277-2285. CrossRef Medline

Chen WG, Chang Q, Lin Y, Meissner A, West AE, Griffith EC, Jaenisch R, Greenberg ME. 2003. Derepression of BDNF transcription involves calcium-dependent phosphorylation of MeCP2. Science 302:885-889. CrossRef Medline

Cohen-Cory S, Fraser SE. 1995. Effects of brain-derived neurotrophic factor on optic axon branching and remodelling in vivo. Nature 378:192-196. CrossRef Medline

Cohen-Cory S, Escandón E, Fraser SE. 1996. The cellular patterns of BDNF and trkB expression suggest multiple roles for BDNF during Xenopus visual system development. Dev Biol 179:102-115. CrossRef Medline

Cohen-Cory S, Kidane AH, Shirkey NJ, Marshak S. 2010. Brainderived neurotrophic factor and the development of structural neuronal connectivity. Dev Neurobiol 70:271-288. CrossRef Medline

Crespo D, O'Leary DD, Maxwell Cowan W. 1985. Changes in the numbers of optic nerve fibers during late prenatal and postnatal development in the albino rat. Dev Brain Res 19:129-134. CrossRef

Cui Q, Harvey A. 1994. NT-4/5 reduces naturally occurring retinal ganglion cell death in neonatal rats. Neuroreport 5:1882-1884. Medline

Cui Q, Harvey A. 1995. At least two mechanisms are involved in the death of retinal ganglion cells following target ablation in neonatal rats. J Neurosci 15:8143-8155. Medline

Dallimore EJ, Cui Q, Beazley LD, Harvey AR. 2002. Postnatal innervation of the rat superior colliculus by axons of late-born retinal ganglion cells. Eur J Neurosci 16:1295-1304. Medline

Dallimore EJ, Park KK, Pollett MA, Taylor JSH, Harvey AR. 2010. The life, death and regenerative ability of immature and mature rat retinal ganglion cells are influenced by their birthdate. Exp Neurol 225:353-365. CrossRef Medline

Davies AM. 1989. Intrinsic differences in the growth rate of early nerve fibres related to target distance. Nature 337:553-555. CrossRef Medline

Davies AM. 1996. The neurotrophic hypothesis: where does it stand? Philos Trans R Soc Lond B Biol Sci 351:389-394. CrossRef Medline

Davies AM, Bandtlow C, Heumann R, Korsching S, Rohrer H, Thoenen $\mathrm{H}$. 1987. Timing and site of nerve growth factor synthesis in developing skin in relation to innervation and expression of the receptor. Nature 326:353-358. CrossRef Medline

Doxakis E, Howard L, Rohrer H, Davies AM. 2008. HAND transcription factors are required for neonatal sympathetic neuron survival. EMBO Rep 9:1041-1047. CrossRef Medline

Dreher B, Potts R, Bennett M. 1983. Evidence that the early postnatal reduction in the number of rat retinal ganglion cells is due to a wave of ganglion cell death. Neurosci Lett 36:255-260. Medline

Dupraz S, Grassi D, Karnas D, Nieto Guil AF, Hicks D, Quiroga S (2013) The insulin-like growth factor 1 receptor is essential for axonal regeneration in adult central nervous system. PLoS One 8:e54462. CrossRef Medline

English J, Pearson G, Wilsbacher J, Swantek J, Karandikar M, Xu S, Cobb MH. 1999. New insights into the control of MAP kinase pathways. Exp Cell Res 253:255-270. CrossRef Medline

Enokido Y, Wyatt S, Davies AM. 1999. Developmental changes in the response of trigeminal neurons to neurotrophins: influence of birthdate and the ganglion environment. Development 126:43654373. Medline

Erskine L, Herrera E. 2007. The retinal ganglion cell axon's journey: Insights into molecular mechanisms of axon guidance. Dev Bio 308:1-14. CrossRef Medline

Feldheim DA, Kim Y-I, Bergemann AD, Frisén J, Barbacid M, Flanagan JG. 2000. Genetic analysis of ephrin-A2 and ephrin-A5 shows their requirement in multiple aspects of retinocollicular mapping. Neuron 25:563-574. Medline

Fischer D. 2012. Stimulating axonal regeneration of mature retinal ganglion cells and overcoming inhibitory signaling. Cell Tissue Res 349:79-85. CrossRef Medline

Fischer D, Petkova V, Thanos S, Benowitz LI. 2004. Switching mature retinal ganglion cells to a robust growth state in vivo: Gene expression and synergy with RhoA inactivation. J Neurosci 24: 8726-8740. CrossRef Medline

Frost DO, Ma Y-T, Hsieh T, Forbes ME, Johnson JE. 2001. Developmental changes in BDNF protein levels in the hamster retina and superior colliculus. J Neurobiol 49:173-187. Medline

Fu Q-L, Hu B, Wu W, Pepinsky RB, Mi S, So K-F. 2008. Blocking LINGO-1 function promotes retinal ganglion cell survival following ocular hypertension and optic nerve transection. Invest Ophthalmol Vis Sci 49:975-985. CrossRef Medline

Fuerst PG, Koizumi A, Masland RH, Burgess RW. 2008. Neurite arborization and mosaic spacing in the mouse retina require DSCAM. Nature 451:470-474. CrossRef Medline 
Fuerst PG, Bruce F, Tian M, Wei W, Elstrott J, Feller MB, Erskine L, Singer JH, Burgess RW. 2009. DSCAM and DSCAML1 function in self-avoidance in multiple cell types in the developing mouse retina. Neuron 64:484-497. CrossRef Medline

Gao Y, Nikulina E, Mellado W, Filbin MT. 2003. Neurotrophins elevate cAMP to reach a threshold required to overcome inhibition by MAG through extracellular signal-regulated kinase-dependent inhibition of phosphodiesterase. J Neurosci 23:11770-11777. Medline

Goldberg JL, Espinosa JS, Xu Y, Davidson N, Kovacs GTA, Barres BA. 2002. Retinal ganglion cells do not extend axons by default: Promotion by neurotrophic signaling and electrical activity. Neuron 33:689-702. Medline

Goodhill GJ, Richards LJ. 1999. Retinotectal maps: molecules, models and misplaced data. Trends Neurosci 22:529-534. Medline

Graef IA, Wang F, Charron F, Chen L, Neilson J, Tessier-Lavigne M, Crabtree GR. 2003. Neurotrophins and netrins require calcineurin/ NFAT signaling to stimulate outgrowth of embryonic axons. Cell 113:657-670. Medline

Gutiérrez-Ospina G, Gutiérrez de la Barrera A, Larriva J, Giordano M (2002) Insulin-like growth factor 1 partly prevents axon elimination in the neonate rat optic nerve. Neurosci Lett 325:207-210. Medline

Hamburger V, Yip J. 1984. Reduction of experimentally induced neuronal death in spinal ganglia of the chick embryo by nerve growth factor. J Neurosci 4:767-774. Medline

Hannila SS, Filbin MT. 2008. The role of cyclic AMP signaling in promoting axonal regeneration after spinal cord injury. Exp Neurol 209:321-332. CrossRef Medline

Harvey AR, Robertson D. 1992. Time-course and extent of retinal ganglion cell death following ablation of the superior colliculus in neonatal rats. J Comp Neurol 325:83-94. CrossRef Medline

Harvey AR, Ooi JWW, Rodger J. 2012. Neurotrophic factors and the regeneration of adult retinal ganglion cell axons. Int Rev Neurobiol 106:1-34. CrossRef Medline

Hausott B, Kurnaz I, Gajovic S, Klimaschewski L. 2009. Signaling by neuronal tyrosine kinase receptors: relevance for development and regeneration. Anat Rec 292:1976-1985. CrossRef Medline

Hellström M, Muhling J, Ehlert EM, Verhaagen J, Pollett MA, Hu Y, Harvey AR. 2011. Negative impact of rAAV2 mediated expression of SOCS3 on the regeneration of adult retinal ganglion cell axons. Mol Cell Neurosci 46:507-515. CrossRef Medline

Hisaoka T. 2006. Characterization of TROY/TNFRSF19/TAJexpressing cells in the adult mouse forebrain. Brain Res 1110:81. CrossRef Medline

Hong Cai J, Deng S, Kumpf S, Lee P, Zagouras P, Ryan A, Gallagher D. 2007 Validation of rat reference genes for improved quantitative gene expression analysis using low density arrays. Biotechniques 42:503-512. Medline

Hu B, Nikolakopoulou AM, Cohen-Cory S. 2005. BDNF stabilizes synapses and maintains the structural complexity of optic axons in vivo. Development 132:4285-4298. CrossRef Medline

Isenmann S, Cellerino A, Gravel C, Bähr M. 1999. Excess targetderived brain-derived neurotrophic factor preserves the transient uncrossed retinal projection to the superior colliculus. Mol Cell Neurosci 14:52-65. CrossRef Medline

Isenmann S, Kretz A, Cellerino A. 2003. Molecular determinants of retinal ganglion cell development, survival, and regeneration. Prog Ret Eye Res 22:483-543. Medline

Jansen P, Giehl K, Nyengaard JR, Teng K, Lioubinski O, Sjoegaard SS, Breiderhoff T, Gotthardt M, Lin F, Eilers A, Petersen CM, Lewin GR, Hempstead BL, Willnow TE, Nykjaer A. 2007. Roles for the pro-neurotrophin receptor sortilin in neuronal development, aging and brain injury. Nat Neurosci 10:1449-1457. CrossRef Medline

Jiao J, Huang X, Feit-Leithman RA, Neve RL, Snider W, Dartt DA, Chen DF. 2005. Bcl-2 enhances $\mathrm{Ca}(2+)$ signaling to support the intrinsic regenerative capacity of CNS axons. EMBO J 24:10681078. CrossRef Medline

Johnson EC, Guo Y, Cepurna WO, Morrison JC. 2009. Neurotrophin roles in retinal ganglion cell survival: Lessons from rat glaucoma models. Exp Eye Res 88:808-815. CrossRef Medline
Johnson JE, Barde YA, Schwab M, Thoenen H. 1986. Brain-derived neurotrophic factor supports the survival of cultured rat retinal ganglion cells. J Neurosci 6:3031-3038. Medline

Kaplan DR, Miller FD (2000) Neurotrophin signal transduction in the nervous system. Curr Opin Neurobiol 10:381-391. Medline

Karpova NN. 2014. Role of BDNF epigenetics in activity-dependent neuronal plasticity. Neuropharmacology 76:709-718. CrossRef

Kermer P, Klöcker N, Labes M, Bähr M (2000) Insulin-like growth factor-I protects axotomized rat retinal ganglion cells from secondary death via PI3-K-dependent Akt phosphorylation and inhibition of caspase-3 in vivo. J Neurosci 20:2-8. Medline

Koeberle PD, Bähr M. 2004. Growth and guidance cues for regenerating axons: where have they gone? J Neurobiol 59:162-180. CrossRef Medline

Konishi Y, Stegmüller J, Matsuda T, Bonni S, Bonni A. 2004. Cdh1APC controls axonal growth and patterning in the mammalian brain. Science 303:1026-1030. CrossRef Medline

Korsmeyer SJ. 1999. Bcl-2 gene family and the regulation of programmed cell death. Cancer Res 59:1693s-1700s. Medline

Kuan C, Yang DD, Roy DRS, Davis RJ, Rakic P, Flavell RA. 1999. The Jnk1 and Jnk2 protein kinases are required for regional specific apoptosis during early brain development. Neuron 22:667-676. Medline

Le-Niculescu H, Bonfoco E, Kasuya Y, Claret F, Green DR, Karin M. 1999. Withdrawal of survival factors results in activation of the JNK pathway in neuronal cells leading to Fas ligand induction and cell death. Mol Cell Biol 19:751-763. Medline

Lee R, Kermani P, Teng KK, Hempstead BL. 2001. Regulation of cell survival by secreted proneurotrophins. Science 294:1945-1948. CrossRef Medline

Levi-Montalcini R, Angeletti PU. 1968. Nerve growth factor. Physiol Rev 48:534-569. Medline

Lindqvist N, Lönngren U, Agudo M, Näpänkangas U, Vidal-Sanz M, Hallböök F. 2010. Multiple receptor tyrosine kinases are expressed in adult rat retinal ganglion cells as revealed by single-cell degenerate primer polymerase chain reaction. Ups J Med Sci 115:65-80. CrossRef Medline

Lingor P, Tönges L, Pieper N, Bermel C, Barski E, Planchamp V, Bähr M. 2008. ROCK inhibition and CNTF interact on intrinsic signalling pathways and differentially regulate survival and regeneration in retinal ganglion cells. Brain 131:250-263. CrossRef Medline

Livak KJ, Schmittgen TD. 2001. Analysis of relative gene expression data using real-time quantitative PCR and the $2-\Delta \Delta C T$ method. Methods 25:402-408.

Lom B, Cogen J, Sanchez AL, Vu T, Cohen-Cory S. 2002. Local and target-derived brain-derived neurotrophic factor exert opposing effects on the dendritic arborization of retinal ganglion cells in vivo. J Neurosci 22:7639-7649. Medline

Lonze BE, Ginty DD. 2002. Function and regulation of CREB family transcription factors in the nervous system. Neuron 35:605-623. Medline

Lorber B, Howe ML, Benowitz LI, Irwin N. 2009. Mst3b, an Ste20-like kinase, regulates axon regeneration in mature CNS and PNS pathways. Nat Neurosci 12:1407-1414. CrossRef Medline

Lu Q, Cui Q, Yip HK, So K-F. 2003. c-Jun expression in surviving and regenerating retinal ganglion cells: effects of intravitreal neurotrophic supply. Invest Ophthalmol Vis Sci 44:5342-5348. Medline

Lund R, Bunt AH. 1976. Prenatal development of central optic pathways in albino rats. J Comp Neurol 165:247-264. CrossRef Medline

Ma Y-T, Hsieh T, Forbes ME, Johnson JE, Frost DO. 1998. BDNF injected into the superior colliculus reduces developmental retinal ganglion cell death. J Neurosci 18:2097-2107. Medline

Major DL, Brady-Kalnay SM. 2007. Rho GTPases regulate PTPmumediated nasal neurite outgrowth and temporal repulsion of retinal ganglion cell neurons. Mol Cell Neurosci 34:453-467. CrossRef Medline 
Mandemakers WJ, Barres BA. 2005. Axon regeneration: it's getting crowded at the gates of TROY. Curr Biol 15:R302-R305. CrossRef Medline

Manning BD, Cantley LC. 2007. AKT/PKB signaling: navigating downstream. Cell 129:1261-1274. CrossRef Medline

Marler K, Poopalasundaram S, Broom E, Wentzel C, Drescher U. 2010. Pro-neurotrophins secreted from retinal ganglion cell axons are necessary for ephrinA-p75NTR-mediated axon guidance. Neural Dev 5:30. CrossRef Medline

Marler KJM, Becker-Barroso E, Martínez A, Llovera M, Wentzel C, Poopalasundaram S, Hindges R, Soriano E, Comella J, Drescher U. 2008. A TrkB/EphrinA interaction controls retinal axon branching and synaptogenesis. J Neurosci 28:12700-12712. CrossRef Medline

Marotte L, Vidovic M, Wheeler E, Jhaveri S. 2004. Brain-derived neurotrophic factor is expressed in a gradient in the superior colliculus during development of the retinocollicular projection. Eur J Neurosci 20:843-847. CrossRef Medline

Marshak S, Nikolakopoulou AM, Dirks R, Martens GJ, Cohen-Cory S. 2007. Cell-autonomous TrkB signaling in presynaptic retinal ganglion cells mediates axon arbor growth and synapse maturation during the establishment of retinotectal synaptic connectivity. J Neurosci 27:2444-2456. CrossRef Medline

Mayr B, Montminy M. 2001. Transcriptional regulation by the phosphorylation-dependent factor CREB. Nat Rev Mol Cell Biol 2:599-609. CrossRef Medline

Mazzoni IE, Saïd FA, Aloyz R, Miller FD, Kaplan D. 1999. Ras regulates sympathetic neuron survival by suppressing the p53mediated cell death pathway. J Neurosci 19:9716-9727. Medline

Mettling C, Gouin A, Robinson M, el M'Hamdi H, Camu W, BlochGallego E, Buisson B, Tanaka H, Davies A, Henderson C. 1995. Survival of newly postmitotic motoneurons is transiently independent of exogenous trophic support. J Neurosci 15:3128-3137. Medline

Meyer-Franke A, Kaplan MR, Pfrieger FW, Barres BA. 1995. Characterization of the signaling interactions that promote the survival and growth of developing retinal ganglion cells in culture. Neuron 15:805-819. Medline

Mi S. 2008. Troy/Taj and its role in CNS axon regeneration. Cytokine Growth Factor Rev 19:245-251. CrossRef Medline

Mi S, Lee X, Shao Z, Thill G, Ji B, Relton J, Levesque M, Allaire N, Perrin S, Sands B, Crowell T, Cate RL, McCoy JM, Pepinsky RB. 2004. LINGO-1 is a component of the Nogo-66 receptor/p75 signaling complex. Nat Neurosci 7:221-228. CrossRef Medline

Ming G-I, Song H-j, Berninger B, Inagaki N, Tessier-Lavigne M, Poo M-M. 1999. Phospholipase $C^{-3}$ and phosphoinositide 3-kinase mediate cytoplasmic signaling in nerve growth cone guidance. Neuron 23:139-148. Medline

Moore DL, Goldberg JL. 2011. Multiple transcription factor families regulate axon growth and regeneration. Dev Neurobiol 71:11861211. CrossRef Medline

Moore DL, Blackmore MG, Hu Y, Kaestner KH, Bixby JL, Lemmon VP, Goldberg JL. 2009. KLF family members regulate intrinsic axon regeneration ability. Science 326:298-301. CrossRef Medline

Nadal-Nicolás FM, Jiménez-López $M$, Sobrado-Calvo $P$, NietoLópez L, Cánovas-Martínez I, Salinas-Navarro M, Vidal-Sanz M, Agudo M. 2009. Brn3a as a marker of retinal ganglion cells: qualitative and quantitative time course studies in naive and optic nerve-injured retinas. Invest Ophthalmol Vis Sci 50:3860-3868. CrossRef Medline

Nadal-Nicolás FM, Jiménez-López M, Salinas-Navarro M, SobradoCalvo P, Alburquerque-Béjar JJ, Vidal-Sanz M, Agudo-Barriuso M. 2012. Whole number, distribution and co-expression of Brn3 transcription factors in retinal ganglion cells of adult albino and pigmented rats. PLoS One 7:e49830. CrossRef Medline

$\mathrm{Ng}$ YP, Cheung ZH, Ip NY. 2006. STAT3 as a downstream mediator of Trk signaling and functions. J Biol Chem 281:15636-15644. CrossRef Medline

Nikoletopoulou V, Lickert H, Frade JM, Rencurel C, Giallonardo P, Zhang L, Bibel M, Barde Y-A. 2010. Neurotrophin receptors TrkA and TrkC cause neuronal death whereas TrkB does not. Nature 467:59-63. CrossRef Medline

Numakawa T, Suzuki S, Kumamaru E, Adachi N, Richards M, Kunugi H. 2010. BDNF function and intracellular signaling in neurons. Histol Histopathol 25:237-258. Medline

O'Driscoll C, Donovan M, Cotter TG. 2006. Analysis of apoptotic and survival mediators in the early post-natal and mature retina. Exp Eye Res 83:1482-1492. [PMC] [17011550]

O'Leary DD, Wilkinson DG. 1999. Eph receptors and ephrins in neural development. Curr Opin Neurobiol 9:65-73. [PMC] [10072375]

Oppenheim RW. 1991. Cell death during development of the nervous system. Annu Rev Neurosci 14:453-501. CrossRef Medline

Osterhout JA, El-Danaf RN, Nguyen PL, Huberman AD. 2014. Birthdate and outgrowth timing predict cellular mechanisms of axon target matching in the developing visual pathway. Cell Rep 8:1006-1017. CrossRef Medline

Park H, Poo M-M. 2013. Neurotrophin regulation of neural circuit development and function. Nature Rev Neurosci 14:7-23. CrossRef Medline

Park JB, Yiu G, Kaneko S, Wang J, Chang J, He Z. 2005. A TNF receptor family member, TROY, is a coreceptor with Nogo receptor in mediating the inhibitory activity of myelin inhibitors. Neuron 45:345-351. CrossRef Medline

Park K, Luo J-M, Hisheh S, Harvey AR, Cui Q. 2004. Cellular mechanisms associated with spontaneous and ciliary neurotrophic factor-cAMP-induced survival and axonal regeneration of adult retinal ganglion cells. J Neurosci 24:10806-10815. CrossRef Medline

Park KK, Liu K, Hu Y, Smith PD, Wang C, Cai B, Xu B, Connolly L, Kramvis I, Mustafa S, Zhigang H. 2008. Promoting axon regeneration in the adult CNS by modulation of the PTEN/mTOR pathway. Science 322:963-966. CrossRef Medline

Park KK, Hu Y, Muhling J, Pollett MA, Dallimore EJ, Turnley AM, Cui Q, Harvey AR. 2009. Cytokine-induced SOCS expression is inhibited by CAMP analogue: impact on regeneration in injured retina. Mol Cell Neurosci 41:313-324. CrossRef Medline

Pearse DD. 2004. Targeting intracellular signaling molecules within the neuron to promote repair after spinal cord injury. Top Spinal Cord Inj Rehab 10:1-16. CrossRef

Perkinton MS, Ip J, Wood GL, Crossthwaite AJ, Williams RJ. 2002. Phosphatidylinositol 3-kinase is a central mediator of NMDA receptor signalling to MAP kinase (Erk1/2), Akt/PKB and CREB in striatal neurones. J Neurochem 80:239-254. Medline

Perry VH. 1981. Evidence for an amacrine cell system in the ganglion cell layer of the rat retina. Neuroscience 6:931-944. Medline

Perry VH, Henderson Z, Linden R. 1983. Postnatal changes in retinal ganglion cell and optic axon populations in the pigmented rat. $J$ Comp Neurol 219:356-368. CrossRef Medline

Peterson WM, Wang Q, Tzekova R, Wiegand SJ. 2000. Ciliary neurotrophic factor and stress stimuli activate the Jak-STAT pathway in retinal neurons and glia. J Neurosci 20:4081-4090. Medline

Pfaffl MW. 2001. A new mathematical model for relative quantification in real-time RT-PCR. Nucleic Acids Res 29:e45. Medline

Pollock GS, Robichon R, Boyd KA, Kerkel KA, Kramer M, Lyles J, Ambalavanar R, Khan A, Kaplan DR, Williams RW, Frost DO. 2003. TrkB receptor signaling regulates developmental death dynamics, but not final number, of retinal ganglion cells. J Neurosci 23: 10137-10145.

Poopalasundaram S, Marler KJM, Drescher U. 2011. EphrinA6 on chick retinal axons is a key component for p75(NTR)-dependent axon repulsion and TrkB-dependent axon branching. Mol Cell Neurosci 47:131-136. CrossRef Medline

Rapaport DH, Wong LL, Wood ED, Yasumura D, LaVail MM. 2004. Timing and topography of cell genesis in the rat retina. J Comp Neurol 474:304-324. CrossRef Medline

Rauskolb S, Zagrebelsky M, Dreznjak A, Deogracias R, Matsumoto T, Wiese S, Erne B, Sendtner M, Schaeren-Wiemers N, Korte M. 2010. Global deprivation of brain-derived neurotrophic factor in 
the CNS reveals an area-specific requirement for dendritic growth. J Neurosci 30:1739-1749. CrossRef Medline

Reber M, Burrola P, Lemke G. 2004. A relative signalling model for the formation of a topographic neural map. Nature 431:847-853. CrossRef Medline

Reese BE, Colello RJ. 1992. Neurogenesis in the retinal ganglion cell layer of the rat. Neuroscience 46:419-429. Medline

Reichardt LF. 2006. Neurotrophin-regulated signalling pathways. Philos Trans R Soc Lond B Biol Sci 361:1545-1564. CrossRef Medline

Rickman DW, Brecha NC. 1995. Expression of the proto-oncogene, trk, receptors in the developing rat retina. Vis Neurosci 12:215222. Medline

Rodriguez-Gil DJ, Bartel DL, Jaspers AW, Mobley AS, Imamura F, Greer CA. 2015. Odorant receptors regulate the final glomerular coalescence of olfactory sensory neuron axons. Proc Natl Acad Sci USA. 112:5821-5826. CrossRef Medline

Rodriguez-Tébar A, Jeffrey PL, Thoenen H, Barde Y-A. 1989. The survival of chick retinal ganglion cells in response to brain-derived neurotrophic factor depends on their embryonic age. Dev Biol 136:296-303. Medline

Rohrer B, LaVail MM, Jones KR, Reichardt LF. 2001. Neurotrophin receptor TrkB activation is not required for the postnatal survival of retinal ganglion cells in vivo. Exp Neurol 172:81-91. CrossRef Medline

Roux PP, Barker PA. 2002. Neurotrophin signaling through the p75 neurotrophin receptor. Prog Neurobiol 67:203-233. Medline

Sanders EJ, Parker E, Harvey S. 2008. Growth hormone-mediated survival of embryonic retinal ganglion cells: signaling mechanisms. Gen Comp Endocrinol 156:613. CrossRef Medline

Schaden H, Stuermer CAO, Bähr M. 1994. Gap-43 immunoreactivity and axon regeneration in retinal ganglion cells of the rat. $\mathrm{J} \mathrm{Neu-}$ robiol 25:1570-1578. CrossRef Medline

Schiller MR. 2006. Coupling receptor tyrosine kinases to Rho GTPases-GEFs what's the link. Cell Signal 18:1834-1843. CrossRef Medline

Schmittgen TD, Livak KJ. 2008. Analyzing real-time PCR data by the comparative $C(T)$ method. Nature Protocols 3:1101-1108. Medline

Schwab ME. 2004. Nogo and axon regeneration. Curr Opin Neurobiol 14:118-124. CrossRef Medline

Sefton AJ, Dreher B, Harvey AR. 2004. Visual system. In: The rat nervous system, ed 3 (Paxinos G, ed), pp 1083-1165. San Diego: Academic Press.[CrossRef]

Segal RA. 2003. Selectivity in neurotrophin signaling: theme and variations. Annu Rev Neurosci 26:299-330. CrossRef Medline

Seijffers R, Allchorne AJ, Woolf CJ. 2006. The transcription factor ATF-3 promotes neurite outgrowth. Mol Cell Neurosci 32:143-154. CrossRef Medline

Spalding KL, Cui Q, Harvey AR. 1998. The effects of central administration of neurotrophins or transplants of fetal tectal tissue on retinal ganglion cell survival following removal of the superior colliculus in neonatal rats. Dev Brain Res 107:133-142. Medline

Spalding KL, Rush RA, Harvey AR. 2004. Target-derived and locally derived neurotrophins support retinal ganglion cell survival in the neonatal rat retina. J Neurobiol 60:319-327. CrossRef Medline

Spalding KL, Cui Q, Harvey AR. 2005. Retinal ganglion cell neurotrophin receptor levels and trophic requirements following target ablation in the neonatal rat. Neuroscience 131:387-395. CrossRef Medline

Stahl N, Yancopoulos GD. 1994. The tripartite CNTF receptor complex: activation and signaling involves components shared with other cytokines. J Neurobiol 25:1454-1466. CrossRef Medline

Sun F, He Z. 2010. Neuronal intrinsic barriers for axon regeneration in the adult CNS. Curr Opin Neurobiol 20:510-518. CrossRef Medline

Suzuki A, Nomura S, Morii E, Fukuda Y, Kosaka J. 1998. Localization of mRNAs for trkB isoforms and p75 in rat retinal ganglion cells. J Neurosci Res 54:27-37. Medline
Tao X, Finkbeiner S, Arnold DB, Shaywitz AJ, Greenberg ME. 1998. $\mathrm{Ca} 2+$ influx regulates BDNF transcription by a CREB family transcription factor-dependent mechanism. Neuron 20:709-726. Medline

Tedeschi A. 2012. Tuning the orchestra: transcriptional pathways controlling axon regeneration. Front Mol Neurosci 4:60. CrossRef

Teng KK, Felice S, Kim T, Hempstead BL. 2010. Understanding proneurotrophin actions: recent advances and challenges. Dev Neurobiol 70:350-359. CrossRef Medline

Thoenen H, Barde YA. 1980. Physiology of nerve growth factor. Physiol Rev 60:1284-1335. Medline

Tokuoka H, Yoshida T, Matsuda N, Mishina M. 2002. Regulation by glycogen synthase kinase-3beta of the arborization field and maturation of retinotectal projection in zebrafish. J Neurosci 22:1032410332. Medline

Trimarchi JM, Stadler MB, Roska B, Billings N, Sun B, Bartch B, Cepko CL. 2007. Molecular heterogeneity of developing retinal ganglion and amacrine cells revealed through single cell gene expression profiling. J Comp Neurol 502:1047-1065. CrossRef Medline

Ugolini G, Cremisi F, Maffei L. 1995. TrkA, TrkB and p75 mRNA expression is developmentally regulated in the rat retina. Brain Res 704:121-124. Medline

Ullian E, Barkis W, Chen S, Diamond J, Barres B. 2004. Invulnerability of retinal ganglion cells to NMDA excitotoxicity. Mol Cell Neurosci 26:544-557. CrossRef Medline

Varendi K, Kumar A, Härma M-A, Andressoo J-O. 2014. miR-1, miR-10b, miR-155, and miR-191 are novel regulators of BDNF. Cell Mol Life Sci 71:4443-4456. CrossRef Medline

Vázquez Chona F, Vazquez C. 2004. Temporal changes in gene expression after injury in the rat retina. Invest Ophthalmol Vis Sci 45:2737.

Vecino E, Garcı"a-Grespo D, Garcı"a M, Martinez-Millán L, Sharma SC, Carrascal E. 2002. Rat retinal ganglion cells co-express brain derived neurotrophic factor (BDNF) and its receptor TrkB. Vis Res 42:151-157. Medline

Veldman MB, Bemben MA, Thompson RC, Goldman D. 2007. Gene expression analysis of zebrafish retinal ganglion cells during optic nerve regeneration identifies KLF6a and KLF7a as important regulators of axon regeneration. Dev Biol 312:596-612. CrossRef Medline

Vogel KS, Davies AM. 1991. The duration of neurotrophic factor independence in early sensory neurons is matched to the time course of target field innervation. Neuron 7:819-830. Medline

Von Bartheld CS. 1998. Neurotrophins in the developing and regenerating visual system. Histol Histopathol 13:437-459. Medline

Voyatzis S, Muzerelle A, Gaspar P, Nicol X. 2012. Modeling activity and target-dependent developmental cell death of mouse retinal ganglion cells ex vivo. PLoS One 7:e31105. CrossRef Medline

Waid DK, McLoon SC. 1995. Immediate differentiation of ganglion cells following mitosis in the developing retina. Neuron 14:117124. Medline

Wang JT, Kunzevitzky NJ, Dugas JC, Cameron M, Barres BA, Goldberg JL. 2007. Disease gene candidates revealed by expression profiling of retinal ganglion cell development. J Neurosci 27:85938603. CrossRef Medline

Weishaupt JH, Klöcker N, Bähr M. 2005. Axotomy-induced early down-regulation of POU-IV class transcription factors Brn-3a and Brn-3b in retinal ganglion cells. J Mol Neurosci 26:17-25. CrossRef Medline

Wilson AM, Di Polo A. 2012. Gene therapy for retinal ganglion cell neuroprotection in glaucoma. Gene Ther 19:127-136. CrossRef Medline

Wright EM, Vogel KS, Davies AM (1992) Neurotrophic factors promote the maturation of developing sensory neurons before they become dependent on these factors for survival. Neuron 9:139-150. Medline

Yip HK, So KF. 2000. Axonal regeneration of retinal ganglion cells: effect of trophic factors. Prog Ret Eye Res 19:559-575. Medline 
Zeng C, Pan F, Jones LA, Lim MM, Griffin EA, Sheline YI, Mintun MA, Holtzman DM, Mach RH. 2010. Evaluation of 5-ethynyl-2'deoxyuridine staining as a sensitive and reliable method for studying cell proliferation in the adult nervous system. Brain Res 1319: 21-32. CrossRef Medline

Zhao HS, Chen SJ, Wu N, Wang XQ, Yin ZQ, Wang Y. 2008. LEDGFp52 controls rat retinal ganglion cell neurite growth in culture and regulates specific neuronal growth-associated genes and protein production. J Int Med Res 36:815. Medline
Zheng F, Zhou X, Moon C, Wang H. 2012. Regulation of brainderived neurotrophic factor expression in neurons. Int $\mathrm{J}$ Physiol Pathophysiol Pharmacol 4:188-200. Medline

Zhou F-Q, Snider WD. 2006. Intracellular control of developmental and regenerative axon growth. Phil Trans Roy Soc B: Biol Sci 361:1575-1592. CrossRef Medline 